\title{
Assessment of the Spatial Relationship between Air Pollutants in Kaduna Metropolis, Nigeria
}

\author{
M. G. Daful ${ }^{1}$, T. O. Adewuyi ${ }^{1}$, M. N. Muhammad ${ }^{2}$, O. A. Oluwole ${ }^{1}$, A. Dadan-Garba ${ }^{1}$ \& C. K. Ezeamaka ${ }^{1}$ \\ ${ }^{1}$ Department of Geography, Nigerian Defence Academy Kaduna, Nigeria \\ ${ }^{2}$ Department of Chemistry, Nigerian Defence Academy Kaduna, Nigeria \\ Correspondence: M. G. Daful, Department of Geography, Nigerian Defence Academy Kaduna, Nigeria. Tel: 234- \\ 70-6947-7274. E-mail: mwanret.daful@nda.edu.ng; daful5mg@gmail.com
}

Received: May 2, $2020 \quad$ Accepted: July 13, $2020 \quad$ Online Published: July 29, 2020

doi:10.5539/jsd.v13n4p204 URL: https://doi.org/10.5539/jsd.v13n4p204

\begin{abstract}
This study analyzes the varying spatial relationship between air pollutants [Carbon monoxide (CO), Sulphur dioxide $\left(\mathrm{SO}_{2}\right)$, Carbon dioxide $\left(\mathrm{CO}_{2}\right)$ and Particulate Matter $\left(\mathrm{PM}_{2.5}\right.$ and $\left.\left.\mathrm{PM}_{10}\right)\right]$ in Kaduna metropolis. This was aimed at having more insight into be characteristics of air pollutants in the study area, which was geared towards efficient environmental management of the city. Validated portable pollutant monitors (MSA Altair 5x Gas Detector $^{\mathrm{a}}, \mathrm{CO}_{2}$ meter Model AZ-0002-DL and CW-HAT200 Particulate Counter) were utilized for data collection, on the concentration of air pollutants $\mathrm{CO}$ and $\mathrm{SO}_{2} ; \mathrm{CO}_{2}$ and particulate matters $\left(\mathrm{PM}_{2.5}\right.$ and $\left.\mathrm{PM}_{10}\right)$ respectively. Pearson correlation and Geographical Weighed Regression (GWR) were used for data analysis, whereas, maps and tables were utilized for data presentation. The findings revealed that a non - perfect positive linear relationship exists between the air pollutants. The GWR model revealed that the distribution of the local $\mathrm{R}^{2}$ values vary spatially across Kaduna Metropolis, indicating that there is a spatially varying relationship between the air pollutants. Higher $\mathrm{R}^{2}$ values were mostly in the central and southern part of the metropolis except for $\mathrm{PM}_{2.5}$ and $\mathrm{PM}_{10}$ in the Northern part of the metropolis. The finding further reveals that $\mathrm{CO}$ has the strongest association with $\mathrm{SO}_{2}, \mathrm{SO}_{2}$ has the strongest association with $\mathrm{PM}_{2.5}$ and $\mathrm{PM}_{10}, \mathrm{CO}_{2}$ with $\mathrm{SO}_{2}, \mathrm{PM}_{10}$ has the highest association with $\mathrm{PM}_{2.5}$, likewise $\mathrm{PM}_{2.5}$ with $\mathrm{PM}_{10}$. The use of GWR to establish the existence of locally varying relationship between the air pollutants was successful. Hence, this study recommends the use of GWR to model air pollutants in cities with limited monitoring capability.
\end{abstract}

Keywords: air pollutants, urban environment, spatial relationship, geographical weighed regression, Nigeria

\section{Introduction}

Breathing clean and pure air is very essential for human health and survival (European Environment Agency World Health Organization (EEA-WHO) 2002), and any changes in the natural or normal composition of air may adversely affects the living system, particularly the human life and invariably causes air pollution (Garg, Garg and Garg, 2006; Aliyu and Botai, 2018). Air is a mixture of odourless, tasteless, colourless and invisible gases usually at the lower atmosphere and covering the earth (Aremu, 2014), Their movement across the earth's surface continually renews the air around us (Mishra, 2008). Therefore, any substance in the air that can cause harm to humans and the environment is known as an air pollutant and air pollutants are expressed as parts per million (ppm) by volume or micrograms per cubic meter of air $\left(\mathrm{ug} / \mathrm{m}^{3}\right)$ which is subjected to variations of temperature and pressure (Das and Behera, 2008). The unceasing existence of these pollutants in the atmosphere ultimately leads to climate change which eventually leads to global warming (Ladan, 2013).

The world is urbanizing and more people (about 55.5\%) lives within urban areas in 2018 (UN, 2019; Satterthwaite, 2007; Odindi, Mhangara and Kakembo, 2012), urban populations coupled with growing levels of motorization and industrialization have inevitably led to air pollution related problems (Matejicek, 2005; Brezzi and SanchezSerra, 2014). The quality of air is a very important factor in projecting or representing the status of environment and health of any region. Worldwide, air pollution has become a major environmental problem in major cities where urban-based activities and residents generate high proportion of gas emissions (Begum, Kim, Biswas and Hoopke, 2004; Revi, Satterthwaite, Aragón-Durand, Corfee-Morlot, Kiunsi, Pelling, Roberts and Solecki, 2014; Aliyu and Botai 2018). Cities such as Shouguang, Beijing and Zhengzhou in China, Yanbu in Saudi Arabia, New Delhi, Wollongong and Mumbai in India, Lagos, Ibadan, Port Harcourt, Kano and Kaduna in Nigeria are 
manifesting increasing air pollution due to rapid urbanization and economic growth. Although there are many other sources of pollution in the urban environment, current observations have shown that more than half the pollution load in cities are due to automobile exhaust and industries (Olajire, Azeez and Oluyemi, 2011; Adedeji, Olasumbo and Oluwaseun, 2016, Paton-Walsh, Guérette, Emmerson, Cope, Kubistin, Humphries, Wilson, Buchholz, Jones, Griffith, Dominick, Galbally, Keywood, Lawson, Harnwell, Ward, Griffiths and Chambers, 2018).

According to the Intergovernmental Panel on Climate Change (IPCC) (2014), emissions of Carbon dioxide $\left(\mathrm{CO}_{2}\right)$ from fossil fuel combustion and industrial processes contributed about $78 \%$ of the total Green House Gas (GHG) emissions increase from 1970 to 2010. Globally, economic and population growth continued to be the most important drivers of increases in $\mathrm{CO}_{2}$ emissions from fossil fuel combustion. The panel conclude that human influence on the climate system is clear, the more human activities disrupt the climate, the more the risk severe, pervasive and irreversible impacts. The need to limit climate change and build a more prosperous, sustainable future is essential. In order to sustain the global environment and improve the quality of living in human settlements, sustainable patterns of production, consumption, transportation and settlements development; pollution prevention; respect for the carrying capacity of ecosystems; and the preservation of opportunities for future generations must be done with great commitment (Habitat II, 1996; Rio, 1992).

The capacity to comprehend the patterns and magnitude of pollution in the urban environment is increasingly important (Smallbone, 1998; Mwenda, 2011) and many developed countries of the world have in place programs for monitoring urban air pollution. These were done by operating a certain number of monitoring stations located in several sites (Allegrini and Costabile, 2002; N'uñez-Alonso, P'erez-Arribas, Manzoor, and C'aceres, 2019), which is however missing in developing countries like Nigeria. There are no proper records or documentation of the urban atmosphere in these countries despite having the fastest growing urban populations (Rahmatizadeh, Delavar and Motessadi, 2003; Agan, 2019). This is because the cost of establishing and implementing ordinary monitoring systems is extremely high; use of analytical instruments are time consuming, expensive, and can seldom be applied for real-time monitoring in the field, though these can give a precise analysis (Hadjimitsis, Nisantzi, Themistocleous, Matsas, and Trigkas, 2010).

Urban air pollutions are becoming problematic because of continuing uncertainty about the causal agents, the likelihood of important interactive and cumulative effects from different pollutants, high levels of both spatial and temporal variability in pollutant concentrations and a scarcity of monitoring data (Bellander, Berglind, Gustavsson, Jonson, Nyberg, Pershagen, and Järup 2001; Zhu, Hinds, Kim and Sioutas. 2002; Briggs, 2007; Banja, Como, Murtaj and Zotaj, 2010; Enkhtur, 2013). Against this background, there is a need for improved information on levels of urban related air pollution, this can be used to help investigate the relationship involved as inputs to health risk assessment, to assist in establishing and monitoring of air quality standards (Raju, Partheeban and Hemamalini, 2012; Dons, Van Poppel, Kochan and Wets, 2013). It has been established that the measuring of urban air pollutants requires a spatial and multivariate data management, which is provided by advances in geographic information systems and earth observations (Wu, 2006; ESRI, 2007; Hadjimitsis et al., 2010; Dubey, 2014; Sameen, Al Kubaisy, Nahhas, Ali, Othman and Hason, 2014; Adedeji et al., 2016).

Therefore, integrating spatial analysis in GIS and statistical modelling can help studies to expand the understanding concerning the distribution of the pollutants in some locations or areas and to understand the factors that influence the trends and their significance (Rahman, Ismail, Raml, Latif, Abidin, and Praveena, 2015; Yao, He, Li, Ma, Li, Yu, Mi, Yu, Wang, Yin and Zhang, 2019). N'uñez-Alonso, P'erez-Arribas, Manzoor, and C'aceres (2019) noted that a number of multivariate approaches can be used in the study of the environment, this is because they provide information about association, modelling and interpretation from large environmental datasets, such as pollutants data. Correlation analysis, Geographical Weighted Regression (GWR) and spatial interpolation are very useful statistical tool to identify the relationship and spatial relationship between pollutants or other variables that affect air quality, and it is very valuable to comprehend or look for the most influential factors or sources of chemical components (Tiwari and Singh, 2014; Zhu, Guo, Xiao, Chen and Yang, 2017)

If the UN Sustainable Development Goals (SDGs), Goal 11: to make cities and human settlements inclusive, safe, resilient and sustainable. Target 11.6: by 2030, reduce the adverse per capita environmental impact of cities, by paying special attention to air quality and municipal and other waste management. Goal 13: take urgent action to combat climate change and its impacts (Gupta and Follette-Cook, 2017) are to be achieve, policy makers require more and more detailed Air Quality (AQ) information to take measures to improve or mitigate its impact (Van de Kassteele et al., 2006; Robichaud, 2016). Thus, this study examines the spatial relationship existing between air pollutants $\left(\mathrm{CO}, \mathrm{SO}_{2}, \mathrm{CO}_{2}, \mathrm{PM}_{2.5}\right.$ and $\left.\mathrm{PM}_{10}\right)$ in Kaduna Metropolis. 


\section{Materials and Methods}

\subsection{Study Area}

Kaduna metropolis is the capital of Kaduna State. The State is located almost at the mid-central portion of the Northern parts of Nigeria and shares common borders with Zamfara (NW), Katsina (N), Niger (SW), Kano (NE), Bauchi (NE), Nasarawa (S), Plateau (SE) States, and the Federal Capital Territory to the South (Nwude, 2006). Kaduna metropolis is located between Latitudes $10^{\circ} 24^{\prime} 39^{\prime \prime} \mathrm{N}$ and $10^{\circ} 36^{\prime} 40^{\prime \prime} \mathrm{N}$ and Longitudes $7^{\circ} 21^{\prime} 26^{\prime \prime} \mathrm{E}$ to $7^{\circ}$ $30^{\prime} 3$ "E of the Greenwich meridian on the high plains of the north central highlands of Nigeria, with a mean elevation of $620 \mathrm{~m}$ amsl and It covers more than 355 square kilometers (Figure 1). Kaduna metropolis is about 912 $\mathrm{Km}$ north of the Gulf of Guinea (Atlantic Ocean), about $530 \mathrm{Km}$ from Nigeria's northern border and $180 \mathrm{Km}$ from the nation's capital city, Abuja. The River Kaduna from which the town derived its name tends to divide the town into two unequal parts. Kaduna metropolis cut across four local governments areas in the state thus: Kaduna North, Kaduna South as well as parts of Igabi and Chikun Local Government Areas (LGAs) (Akpu, 2012).

Kaduna metropolis experienced tropical continental climate with distinct seasonal regimes. The seasonality is characterized with the cool and hot dry season. The area is influenced by the tropical wet and dry climate (AW by Koppen's classification) with seasonal alternation of moist maritime air mass (tropical maritime/SW trade wind), and dry continental air mass (North easterly trade wind/hamattan) (Abaje, Ati, and Ishaya, 2009). The climatic classification of the study area is the tropical continental climate. The dry season starts at the end of October to early March of the following year. Average annual rain fall recorded is $1000 \mathrm{~mm}$ to $1500 \mathrm{~mm}$. The rainfall type is convectional with a single regime of maximum peak, which usually occurs in August/September at a stretch (Parkman International Studies, 1997; Abaje et al., 2009).

The population of Kaduna has grown rapidly from about 14,000 in 1929 to 40,000 in 1952 to 149,000 in 1963 to an estimated 150,000 in 1965 and 500,000 in 1984. The 1991 census put the human population of Kaduna metropolis at 971,070 (NPC, 1991). Based on $2.7 \%$ growth rate, the population was estimated to have reach $1,448,129$ in 2006(NPC, 2009). By 2009, at 3.0\% growth rate, the population was estimated to have hit 1,582,409. The population was projected to reach $1,729,142$ by 2012 . At $3.5 \%$ growth rate the population was estimated to $2,031,742$ in 2017. This high growth rate can be attributed to natural increase and high rate of immigration (National Bureau of Statistics, 2012; Akpu, 2012). 


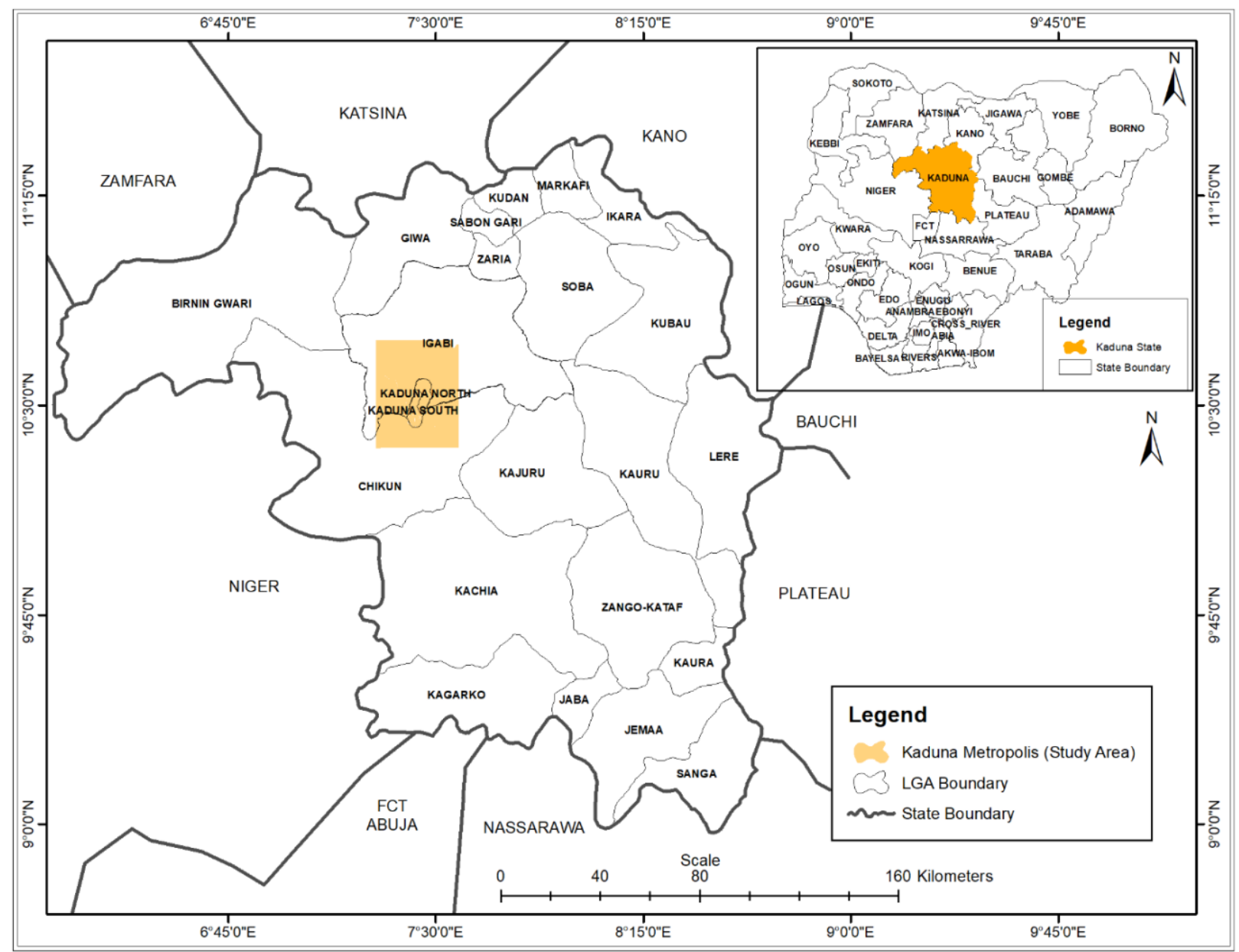

Figure 1. Kaduna metropolis in Kaduna state

Source: KADGIS (2017)

\subsection{Methodology}

The needed information were obtained through direct field survey of the study area, the exercise of measurements and observation of the air quality attributes was carried out, through the use of a handheld air quality monitoring device (MSA Altair 5x Gas Detector ${ }^{\mathrm{a}}$ ) to collect data on the concentration of air pollutants $\left(\mathrm{CO}\right.$, and $\left.\mathrm{SO}_{2}\right), \mathrm{CO}_{2}$ meter (Model AZ-0002-DL) for $\mathrm{CO}_{2}$ and the particulate matter meter (Ch CW-HAT200 Particulate Counter) to test the concentration of particulate matters $\left(\mathrm{PM}_{2.5}\right.$ and $\left.\mathrm{PM}_{10}\right)$. These instruments were used because of the accuracy of the sensors in detecting pollutants within seconds and its mobility.

A total of 33 data collection points were selected, for equal representation of the sample sites across each of the land use. Equal allocation stratify sampling was used to allocated 8 sample sites to each of the land uses except the traffic sites which was allocate the extra one site left making it to have 9 sample sites. Purposive sampling was carried out to select the points across the land uses, this was used because it allowed the researcher to choose sample sites in areas with emission. For the traffic land use, data were collected beside traffic areas, for the industrial and commercial sites, data were collected close to sources of emission, the selected sample sites for this study are as shown in Figure 2.

The study involved integrating air pollutants data from field measurements into digital map layers, this was to aid in showing the spatial distribution of the air pollutants in Kaduna metropolis. Locational coordinates of longitude (x-coordinate), latitude (y-coordinate) and elevation above mean sea level of the sampling sites determined using Garmin Global Positioning System (GPS) device, and also the air pollutant measurements result as recorded in the field was stored in Microsoft excel software using the CSV (comma delimited) format. The excel spread sheet was imported to ArcGIS 10.6 environment and plot as a point map and also converted to shapefile for analysis. Attribute 
data were then assigned to spatial objects and the system become ready for spatial analysis and management.

Geographically Weighted Regression (GWR) is a spatial analysis technique that takes into consideration nonstationary variables (such as climate; demographic factors; physical environment characteristics) and models the local relationships between these predictors and an outcome of interest. The primary idea of GWR is to explore how the relationship between a dependent variable $(\mathrm{Y})$ and one or more independent variables $(\mathrm{X})$ might varies geographically. Instead of assuming a single model can be fitted to the entire study area, it looks for geographic differences (Charlton and Fortheringham, 2009). It is used to determine whether the relationships between the dependent and independent variables varies spatially within a given area (Fortheringgham, Brunsdon and Charlton, 2002; Sabokbar, Roodposhti and Tazik, 2004).

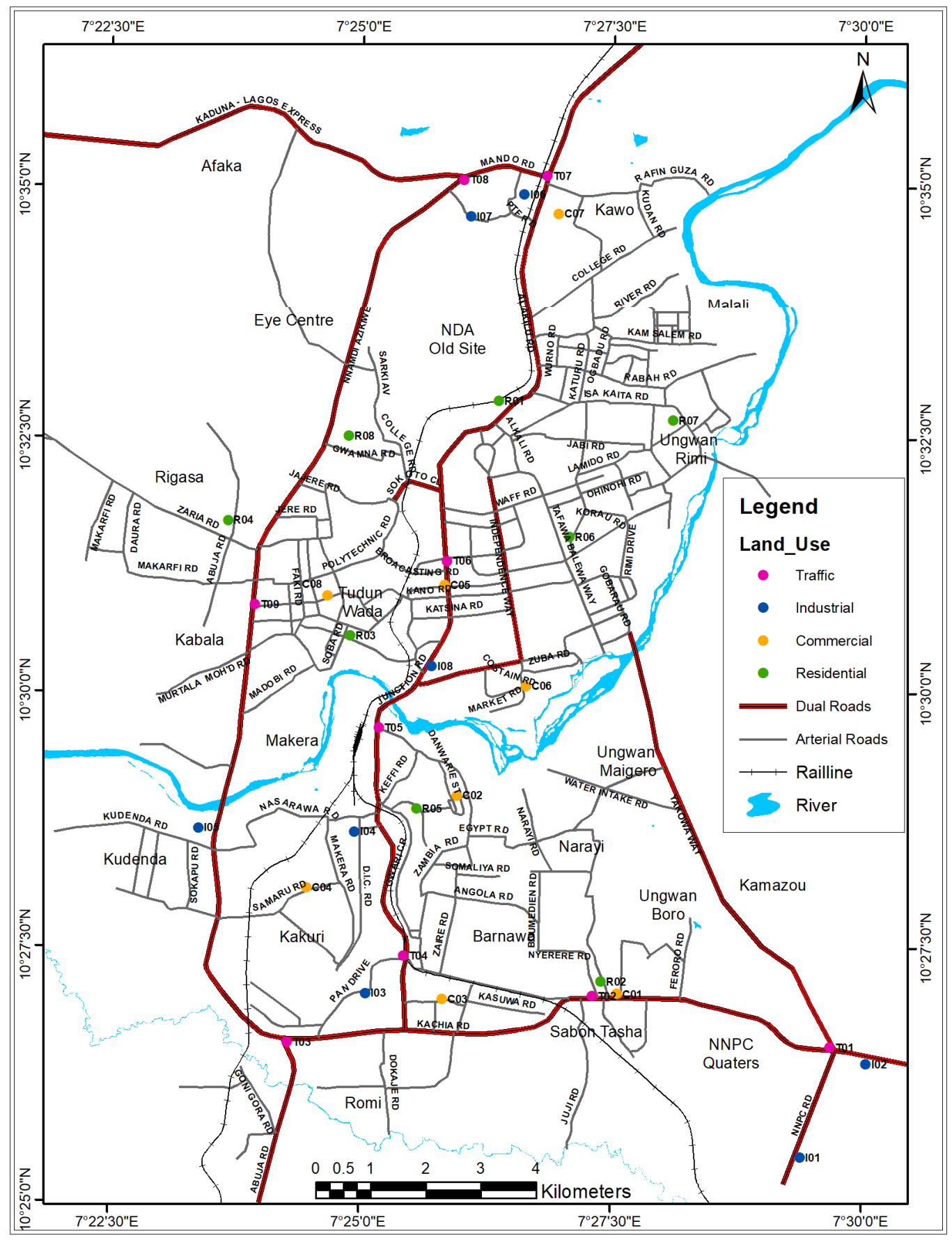

Figure 2. Proposed sample collection points

Source: KADGIS (2017). 
GWR is a local spatial statistical technique that this study employed to analyse spatial non-stationarity of the relationships between variables. GWR emanated from traditional linear regression methods (Eq. 1) by permitting the relationships between variables to vary spatially ( $\mathrm{Lu}$, Mei, Zhang, Liao, Long, Dahlgren and Zhang, 2011; Sabokbar et al., 2004; Azua, 2018):

where:

$$
y_{i}=\beta_{0}+\sum_{i=1}^{k} \beta_{k} x_{i k}+\varepsilon_{i}
$$

$\mathrm{x}_{\mathrm{i}}$ and $\mathrm{y}_{\mathrm{i}}=$ the independent and dependent variables,

$\mathrm{k}=$ the number of independent variables,

$\beta_{\mathrm{i}}$ and $\beta_{\mathrm{k}}=$ the intercept and coefficients, and

$\varepsilon=$ the error

According to Fotheringham et al. (2002), defined GWR is the measurement of relationship among variables differs from the one to another location. This model was applied in this study because the relationships between air pollutants can be inconsistent across time and space. The model is obtained in Eq. 2 (Lu et al., 2011; Sabokbar et al., 2004; Azua, 2018):

where:

$$
y_{j}=\beta_{0}\left(\mu_{j}, v_{j}\right)+\beta_{k}\left(\mu_{j}, v_{j}\right) \chi_{j k}+\varepsilon_{j}
$$

$y_{j}=$ the estimated value of the dependent variable for observation $j$;

$\mu_{\mathrm{j}}, v_{\mathrm{j}}=$ the coordinates of the location of the observation $\mathrm{j}$;

$\beta_{\mathrm{o}}\left(\mu_{\mathrm{j}}, v_{\mathrm{j}}\right)=$ the intercept for sampling educational facility $\mathrm{j}$;

$\beta_{\mathrm{k}}\left(\mu_{\mathrm{j}}, v_{\mathrm{j}}\right) \mathrm{x}_{\mathrm{jk}}=$ the local parameter estimate for educational facility $\mathrm{j}$;

$\varepsilon_{\mathrm{j}}=$ the error terms for sampling educational facility $\mathrm{j}$.

Ordinary Least Squares (OLS) method was used to reveal the global relationship between the air pollutants (dependent variable) and the independent variables before embarking on GWR. This ensured that indeed there exist relationships before undertaking the local relationship. The use of GWR requires certain parameters, such as the Kernel. There are two types of Kernel that are available for use namely; fixed and adaptive Kernel. In this study, the adaptive kernel was used because it offers results that are nearer to reality (Javi, Malekmohammadi and Mokhtai, 2013; Azua, 2018). Other parameters are dependent and independent variables, and bandwidth method and the study adopted the parameters as shown in Table 1.

Table 1. Parameters used in GWR

\begin{tabular}{lll}
\hline & Requirement & Type Adapted \\
\hline 1 & Dependent Variable & Air Pollutants concentration \\
2 & Independent Variables & Air Pollutants concentration $\left(\mathrm{CO}, \mathrm{SO}_{2}, \mathrm{CO}_{2} \mathrm{PM}_{2.5}\right.$ and $\left.\mathrm{PM}_{10}\right)$. \\
3 & Kernel Type & Adaptive \\
4 & Bandwidth Method & Corrected Aikaic Information Criterion (AIC) \\
\hline
\end{tabular}

Source: Field work (2018)

GWR was used to determine a set of local regression results that included local $\mathrm{R}^{2}$ values, local residuals and standard residual (Javi et al, 2013; Azua, 2018). The local $\mathrm{R}^{2}$ values known as the coefficient of determination were used to reveal the ability of the independent variables to explain the variance in the dependent variable at differ locations (Huang, Huang, Pontius and Zhang, 2015). According to Javi et al. (2013), Huang et al. (2015) and Azua (2018), the $\mathrm{R}^{2}$ values ranges from 0 to 1 and higher values (closer to 1 ) means that the independent variable can explain more spatial variance of the dependent variable. While a lower value of $\mathrm{R}^{2}$ (that is closer to 0 ) indicates that the independent variable does not have the ability to explain the spatial variability in the dependent variable.

The local residual is the difference between an observed value and its estimated value returned by the GWR model. This is commonly used as a measure for detecting outliers. The smaller the local residual, the closer the fit of the GWR model to the observed data. However, in this study, the local residual and the $\mathrm{R}^{2}$ were analysed to explain 
the spatial relationship between the air pollutants $\left(\mathrm{CO}, \mathrm{SO}_{2}, \mathrm{CO}_{2}, \mathrm{PM}_{2.5}\right.$ and $\left.\mathrm{PM}_{10}\right)$.

Spatial Interpolation: The result of the local $\mathrm{R}^{2}$ analysis are then subjected to spatial interpolation using Inverse Distance Weighted (IDW) interpolation techniques. This was to aid show the spatial relationship as a surface in the study area.

\section{Results and Discussion}

\subsection{Relationship Between Air Pollutants}

In this section, the strength of the relation between the different air pollutants was analyze using cross tabulation. Table 2 presents the findings

Table 2. The strength of the relationship between air pollutants

\begin{tabular}{llllll}
\hline & $\mathbf{C O}$ & $\mathbf{S O}_{2}$ & $\mathbf{C O}_{2}$ & $\mathbf{P M}_{2.5}$ & $\mathbf{P M}_{10}$ \\
\hline $\mathrm{CO}$ & 1 & & & & \\
$\mathrm{SO} 2$ & 0.788 & 1 & & & \\
$\mathrm{CO} 2$ & 0.624 & 0.768 & 1 & & \\
$\mathrm{PM} 2.5$ & 0.753 & 0.794 & 0.624 & 1 & \\
$\mathrm{PM} 10$ & 0.739 & 0.795 & 0.632 & 0.991 & 1 \\
\hline
\end{tabular}

The finding of the study as shown in Table 2 reveals that a strong positive correlation exists between $\mathrm{CO}$ and the other air pollutants, $\mathrm{SO}_{2}$ and the other pollutants and $\mathrm{CO}_{2}$ and the other pollutants. Hence a non -perfect linear relationship exists between them. While the relationship between $\mathrm{PM}_{2.5}$ and $\mathrm{PM}_{10}$ shows a near perfect linear relationship. Thus, as the concentration of $\mathrm{PM}_{2.5}$ increases so also the concentration of $\mathrm{PM}_{10}$ increases.

\section{Spatial Variation of Relationships between Carbon Monoxide and the other Air Pollutants $\left(\mathrm{SO}_{2}, \mathrm{CO}_{2}, \mathrm{PM}_{2.5}\right.$ and $\mathrm{PM}_{10}$ )}

The findings revealed a corrected Akaike Information Criterion (AICc) value of 267.44, 282.90, 271.34, 272.34 for $\mathrm{SO}_{2}, \mathrm{CO}_{2}, \mathrm{PM}_{2.5}$ and $\mathrm{PM}_{10}$ respectively and $\mathrm{R}^{2}$ value of $0.6288,0.4303,0.5884,0.5749$ similarly for $\mathrm{SO}_{2}, \mathrm{CO}_{2}$, $\mathrm{PM}_{2.5}$ and $\mathrm{PM}_{10}$ respectively. This implies that $\mathrm{SO}_{2}$ can best be used to model the concentration of $\mathrm{CO}$ than the other air pollutants as $62.88 \%$ of the model can be accurately accounted for using $\mathrm{SO}_{2}$. While $\mathrm{CO}_{2}$ perform weekly with an accuracy of $43.03 \%$, thus, $\mathrm{CO}_{2}$ was the weakest predictor, while $\mathrm{SO}_{2}$ was the strongest predictor of $\mathrm{CO}$.

An extract of the local $\mathrm{R}^{2}$ result for carbon monoxide is shown in Figure 3, with the local $\mathrm{R}^{2}$ values with regards to $\mathrm{CO}$ ranges from 0.6517 to 0.3658 . this implies that the local $\mathrm{R}^{2}$ values varies from one point to the other and shows both higher and lower values than the normal $\mathrm{R}^{2}$ values. 


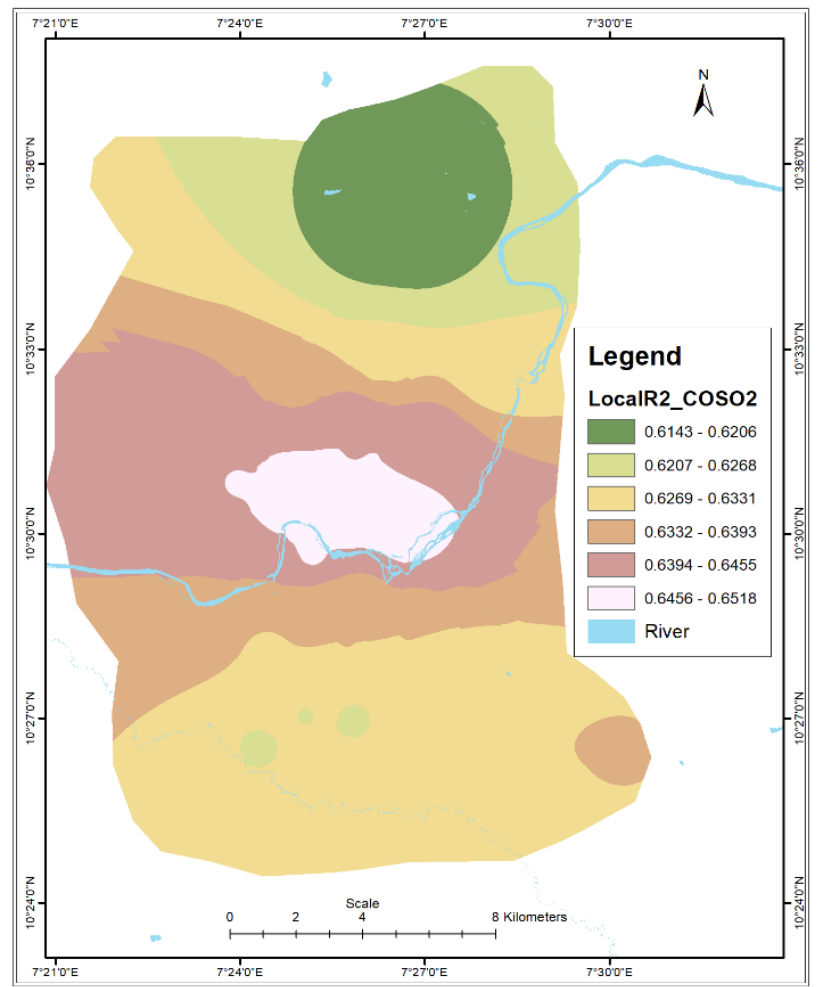

(a): $\mathrm{SO}_{2}$

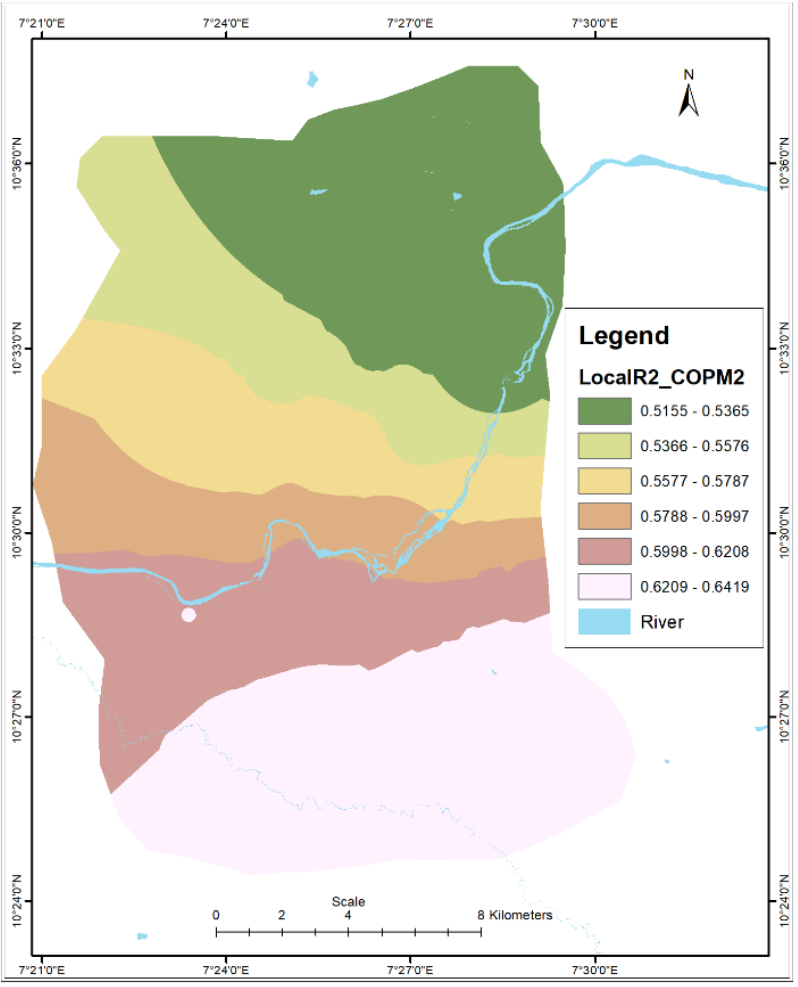

(c): $\mathrm{PM}_{2.5}$

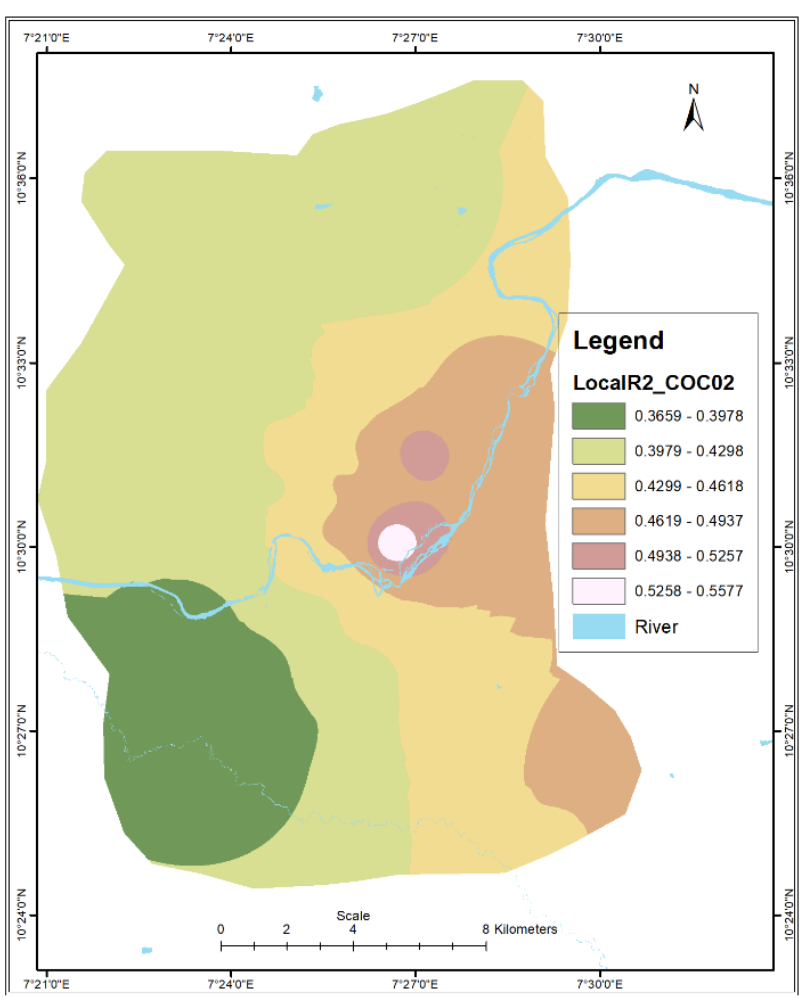

(b): $\mathrm{CO}_{2}$

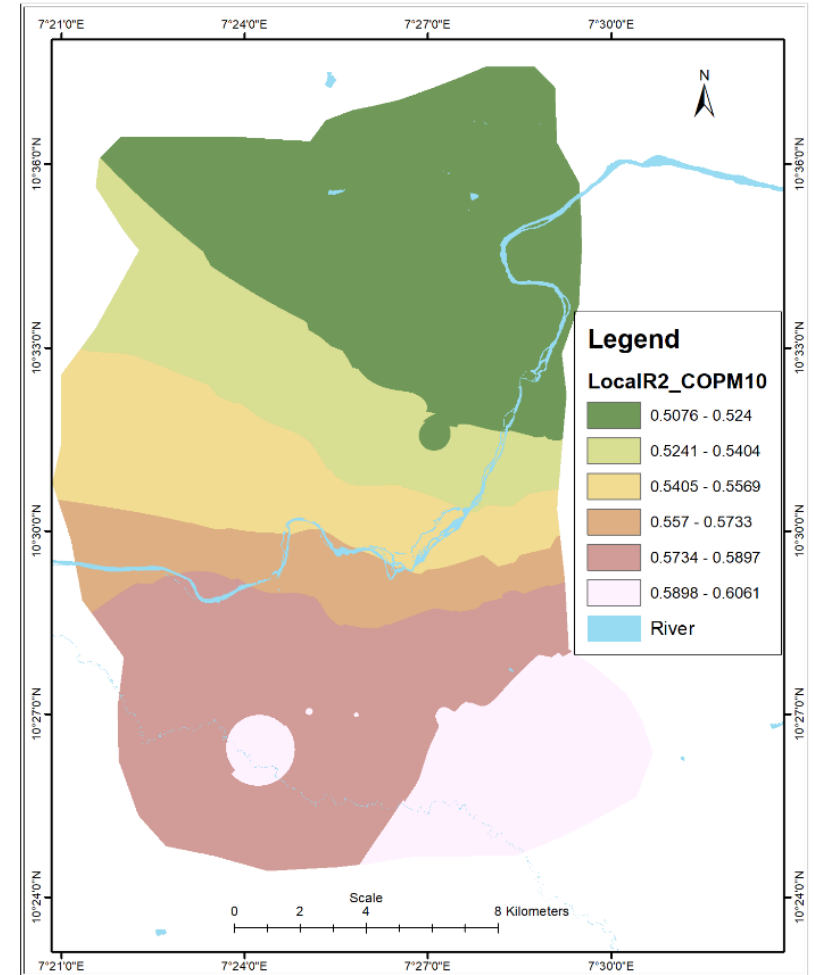

(d): $\mathrm{PM}_{10}$

Figure 3. Spatial variation in local $\mathrm{R}^{2}$ values for carbon monoxide prediction 
The finding further reveals that the model using $\mathrm{SO}_{2}$ to predict $\mathrm{CO}$ has a Local $\mathrm{R}^{2}$ value range of 0.6143 to 0.6518 , and the spatial analysis of its performance shows that the model performs better in the central part and southern part than the northern part of the metropolis. The local $\mathrm{R}^{2}$ for $\mathrm{CO}_{2}$ performance ranges from 0.3695 to 0.5577 . This shows that though the performance of the model prediction using $\mathrm{CO}_{2}$ was week the local $\mathrm{R}^{2}$ as shown in Figure 3 (b) show strong prediction in the eastern part of the metropolis. $\mathrm{PM}_{2.5}$ and $\mathrm{PM}_{10}$ in Figure 3 shows a similar pattern, with a local $\mathrm{R}^{2}$ value range of $0.5076-0.6419$, likewise though the performance the model is strong using the $\mathrm{PM}_{2.5}$ and $\mathrm{PM}_{10}$. The model performs stronger in the southern part of the metropolis than the northern part as shown in Figure 3. This implies that the local $\mathrm{R}^{2}$ changes spatio-temporally for the different pollutants. The model for the prediction of $\mathrm{CO}$ performs better in the southern part than the northern part of the metropolis.

Spatial Variation of Relationships between Sulphur Dioxide and the other Air Pollutants $\left(\mathrm{CO}, \mathrm{CO}_{2}, \mathrm{PM}_{2.5}\right.$ and $\left.\mathrm{PM}_{10}\right)$

The model reveals an AICc value of $-68.35,-71.118,-74.67,-75.97$ for $\mathrm{CO}, \mathrm{CO}_{2}, \mathrm{PM}_{2.5}$ and $\mathrm{PM}_{10}$ respectively and $\mathrm{R}^{2}$ value of $0.6392,0.6973,0.7199,0.7286$ similarly for $\mathrm{CO}, \mathrm{CO}_{2}, \mathrm{PM}_{2.5}$ and $\mathrm{PM}_{10}$ respectively. This implies that Particulate maters $\left(\mathrm{PM}_{2.5}\right.$ and $\left.\mathrm{PM}_{10}\right)$ can best be used to model the concentration of $\mathrm{SO}_{2}$ than the other air pollutants as about $72 \%$ of the model can be accurately accounted for using $\mathrm{PM}_{2.5}$ and $\mathrm{PM}_{10}$. While CO which is the weakest predictor among the pollutants, performance is also strong with an accuracy of about $64 \%$, as the variance accounted for by the regression model for the prediction of $\mathrm{SO}_{2}$.

The result of the local $\mathrm{R}^{2}$ for $\mathrm{SO}_{2}$ with respect to the other air pollutants are shown in Figure 4. the local $\mathrm{R}^{2}$ with respect to $\mathrm{PM}_{2.5}$ and $\mathrm{PM}_{10}$ exhibits some spatial variability ranging from 0.5905 to 0.7153 . Higher $\mathrm{R}^{2}$ values of 0.6722 to 0.7153 with respect to both $\mathrm{PM}_{2.5}$ and $\mathrm{PM}_{10}$, were observed in the southern part of the metropolis, while lower values ranging from 0.5905 to 0.6433 were observed in the northern part of the metropolis (Figure 4 a and c). this implies that $\mathrm{PM}_{2.5}$ and $\mathrm{PM}_{10}$ emission have high association with $\mathrm{SO}_{2}$ emission in Kaduna metropolis, most especially in the southern part of the metropolis. 


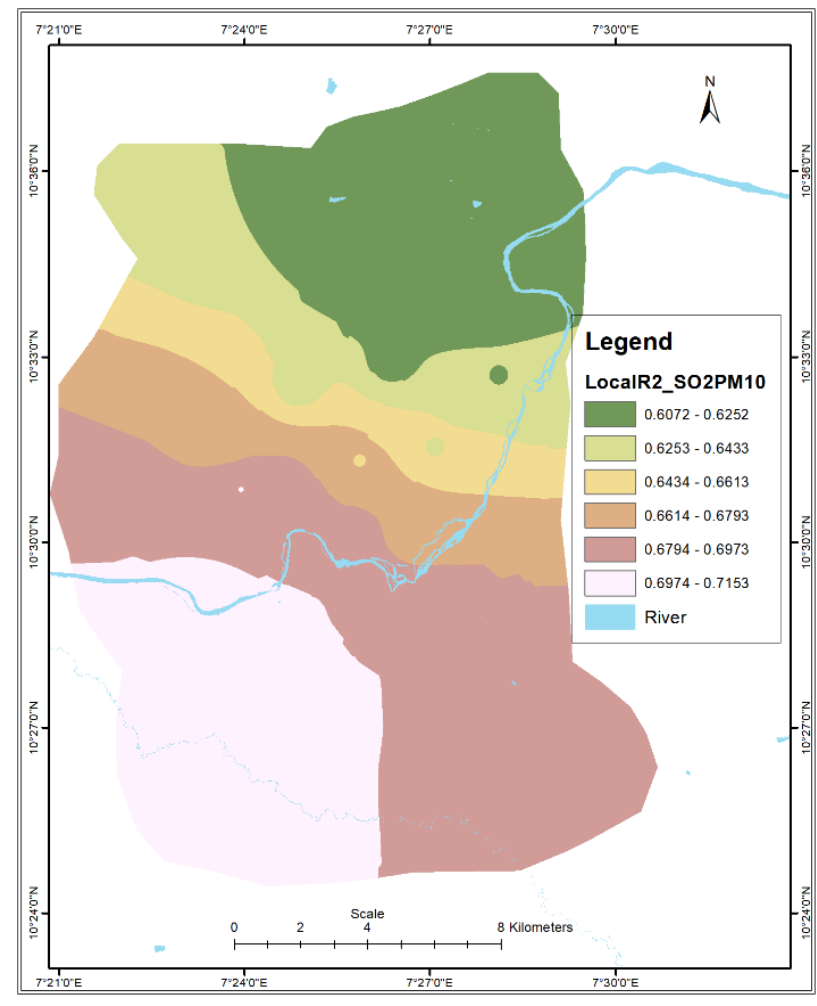

(a): $\mathrm{PM}_{10}$

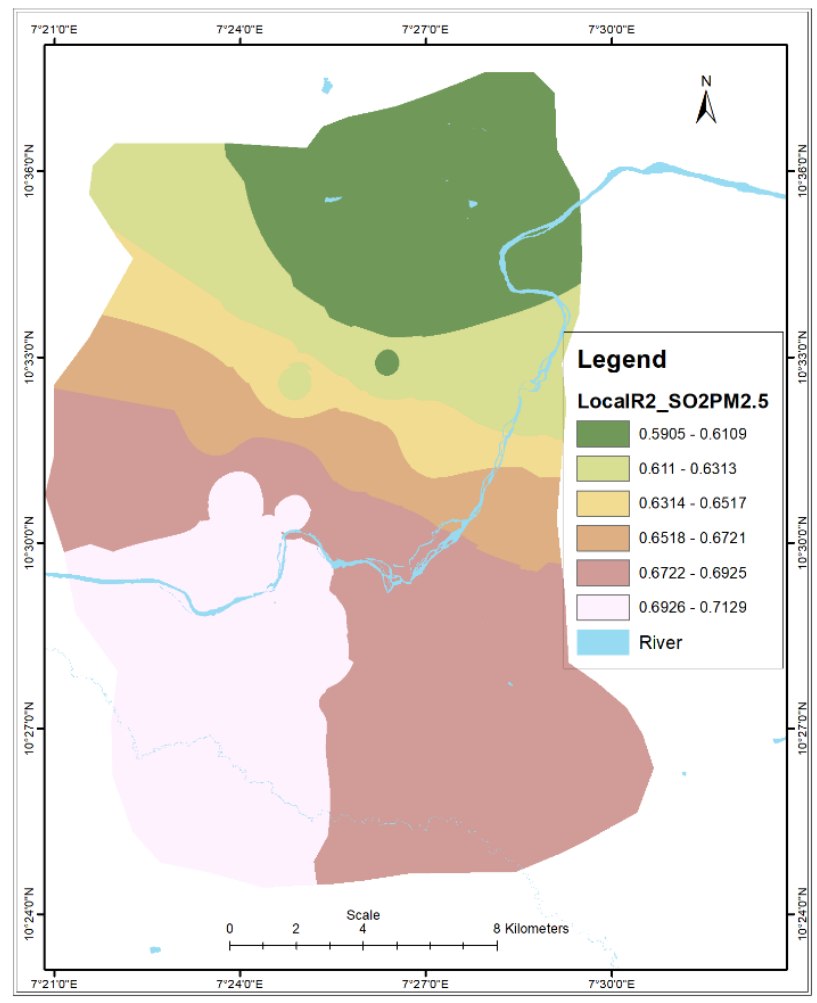

(c): $\mathrm{PM}_{2.5}$

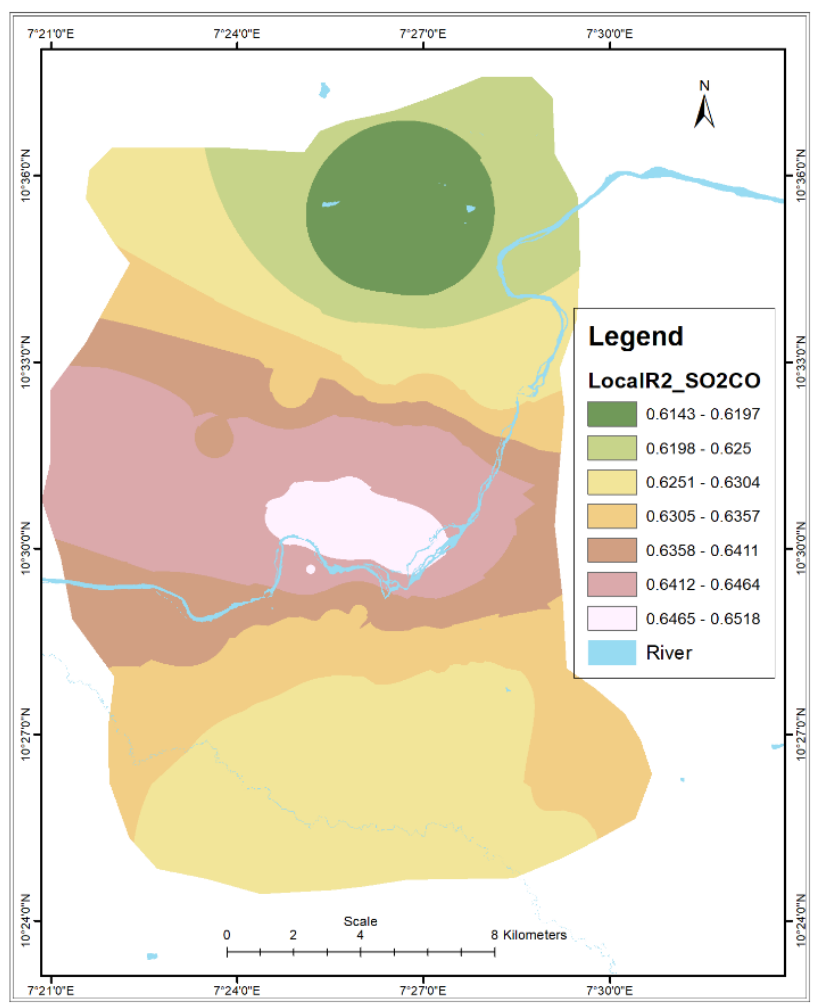

(b): $\mathrm{CO}$

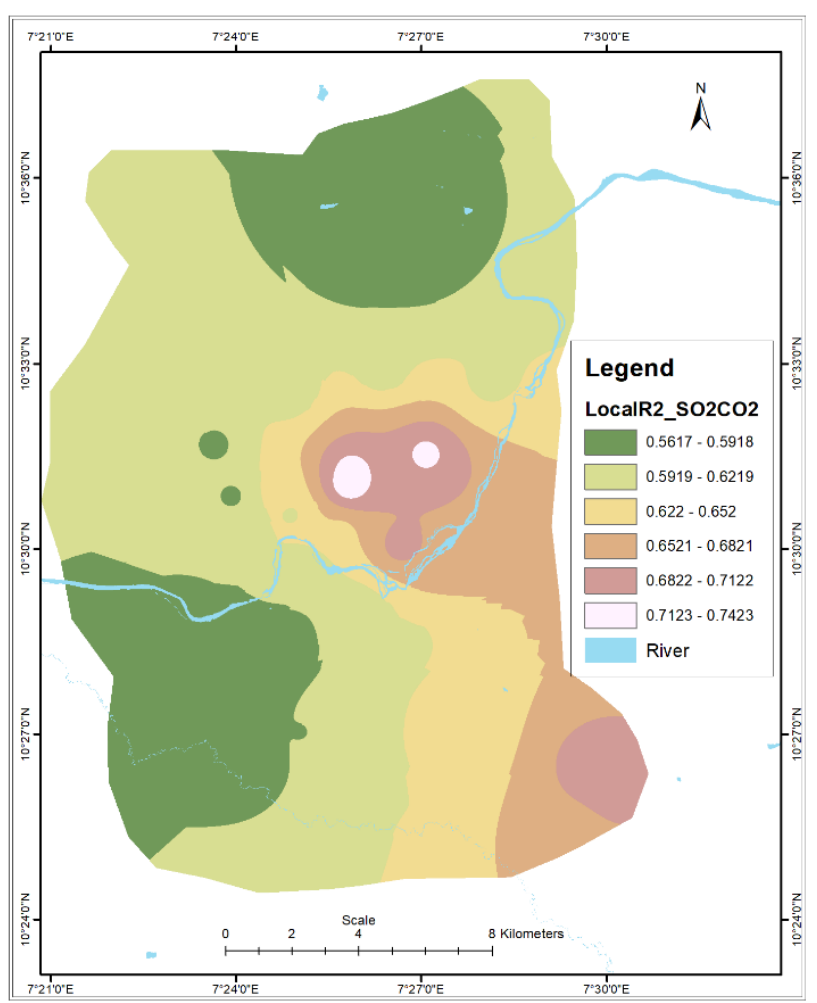

(d): $\mathrm{CO}_{2}$

Figure 4. Spatial variation in local $\mathrm{R}^{2}$ values for sulphur dioxide prediction 
The analysis also shows a moderately strong relationship with $\mathrm{CO}_{2}$ and $\mathrm{CO}$, there Local $\mathrm{R}^{2}$ also varies spatiotemporally across the metropolis ranging from 0.5617 to 0.7423 and 0.6143 to 0.6518 respectively as shown in Figure $4 \mathrm{~b}$ and $\mathrm{d}$. the finding equally shows that the local $\mathrm{R}^{2}$ value for $\mathrm{CO}$ is relatively uniform across the metropolis, higher values ranging between 0.6412 to 0.6518 were observed in the central and western part of the metropolis, while lower values ranging from 0.6143 to 0.625 were observed in the northern part of the metropolis. The local $\mathrm{R}^{2}$ value of $\mathrm{CO}_{2}$ varies spatial across the metropolis, lower values ranging from 0.5617 to 0.6219 were observed in the south western and northern part of the metropolis, while higher values ranging from 0.6822 to 0.7423 were observed in the central and south eastern part of the metropolis. Thus, a moderately strong association exist between $\mathrm{SO}_{2}$ emission and both $\mathrm{CO}$ and $\mathrm{CO}_{2}$ emission in Kaduna metropolis, which varies spatio-temporally.

\section{Spatial Variation of Relationships between Carbon Dioxide and the other Air Pollutants $\left(\mathrm{CO}, \mathrm{SO}_{2}, \mathrm{PM}_{2.5}\right.$ and $\left.\mathrm{PM}_{10}\right)$}

The geographical weighted regression model for $\mathrm{CO}_{2}$ shows a corrected Akaike Information Criterion (AICc) value of $335.45,318.58,331.95,333.85$ for $\mathrm{CO}, \mathrm{SO}_{2}, \mathrm{CO}_{2}$ and $\mathrm{PM}_{10}$ respectively and $\mathrm{R}^{2}$ value of $0.4098,0.8670$, 0.4684, 0.4334 likewise for $\mathrm{CO}, \mathrm{SO}_{2}, \mathrm{CO}_{2}$ and $\mathrm{PM}_{10}$ respectively. This implies that $\mathrm{SO}_{2}$ can best be used to model the concentration of $\mathrm{CO}_{2}$ than the other air pollutants, as about $86.7 \%$ corrected Akaike Information Criterion of the model can be accurately accounted. While $\mathrm{CO}$ is the weakest predictor among the other pollutants, with an accuracy of about $41 \%$, as the variance accounted for by the regression model for the prediction of $\mathrm{CO}_{2}$.

The result of the local $\mathrm{R}^{2}$ of $\mathrm{CO}_{2}$ with respect to the other air pollutants are shown in Figure 5. its local $\mathrm{R}^{2}$ with respect to $\mathrm{SO}_{2}$ exhibits high spatial variability ranging from 0.6986 to 0.914 . Higher $\mathrm{R}^{2}$ values of 0.8064 to 0.914 with respect to $\mathrm{SO}_{2}$, were observed in the south eastern and central part of the metropolis, while lower values ranging from 0.6986 to 0.7704 were observed in the south western part of the metropolis. this implies that $\mathrm{CO}_{2}$ emission have high association with $\mathrm{SO}_{2}$ emission in Kaduna metropolis, most especially in the south eastern part of the metropolis as shown in Figure 5. 


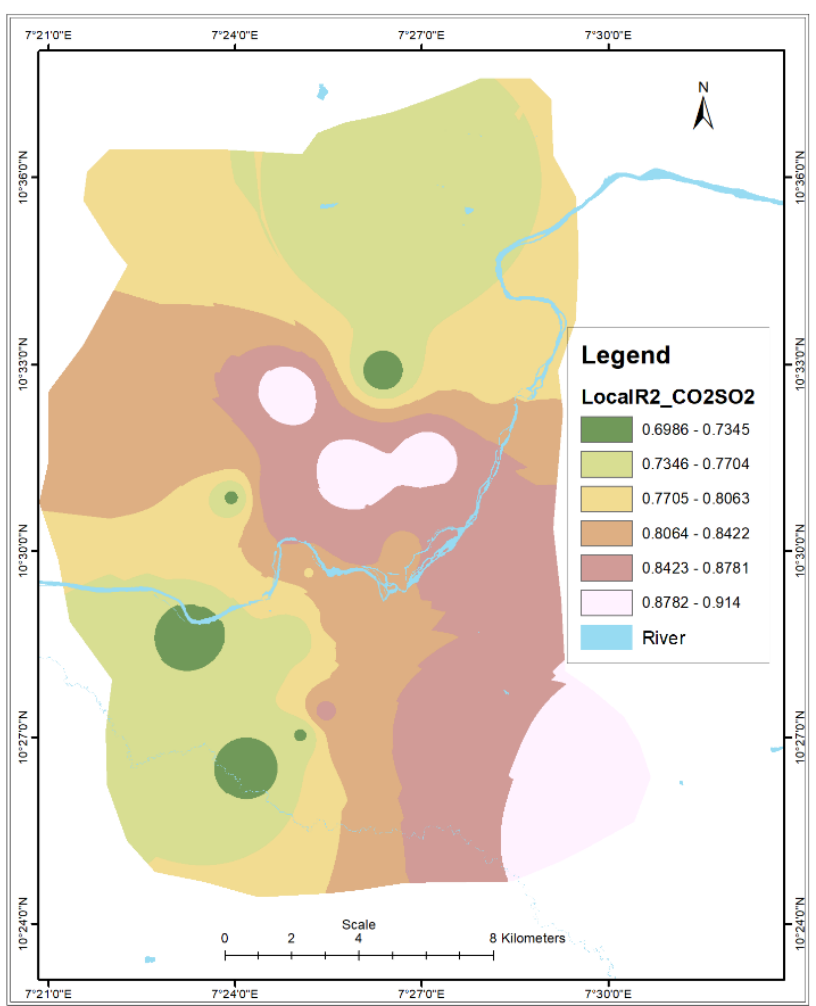

(a): $\mathrm{SO}_{2}$

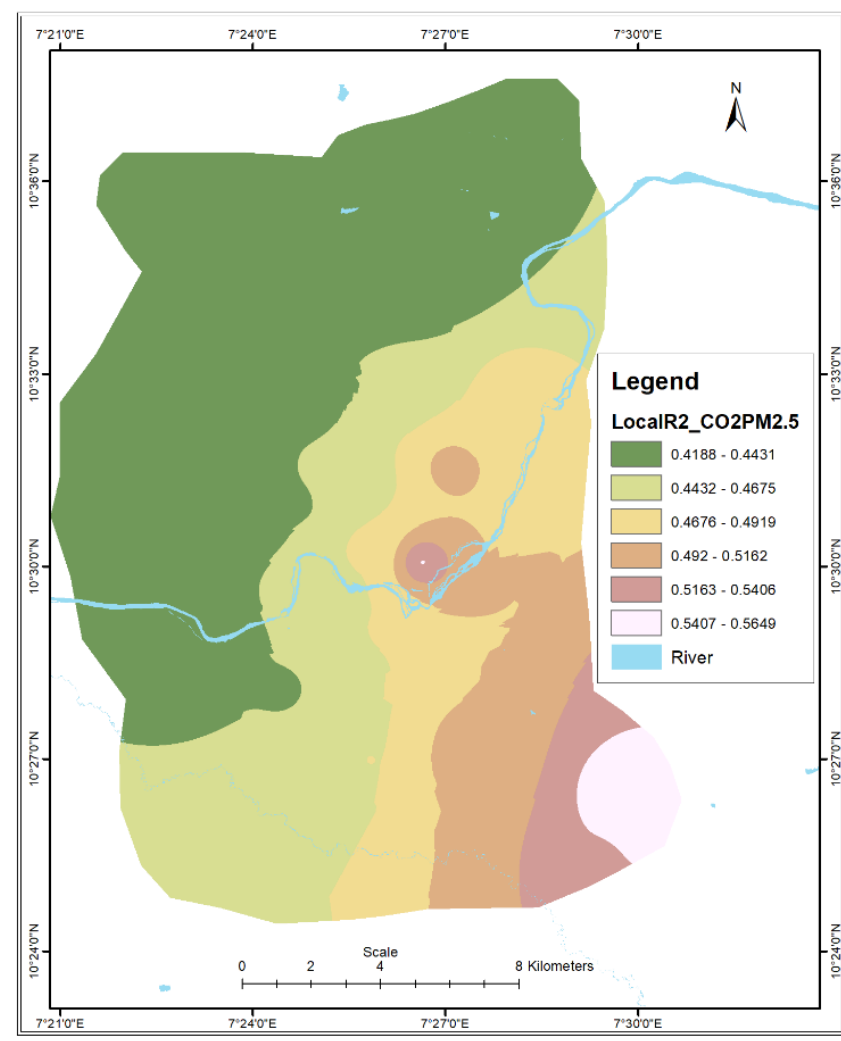

( c): $\mathrm{PM}_{2.5}$

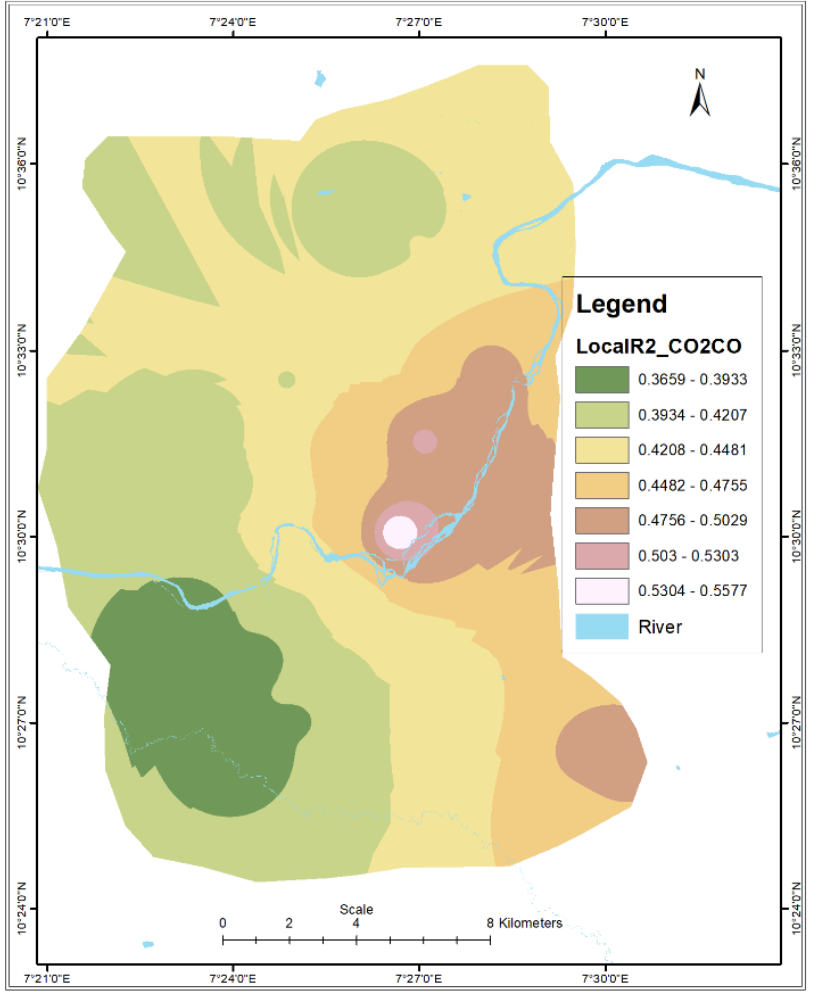

(b): $\mathrm{CO}$

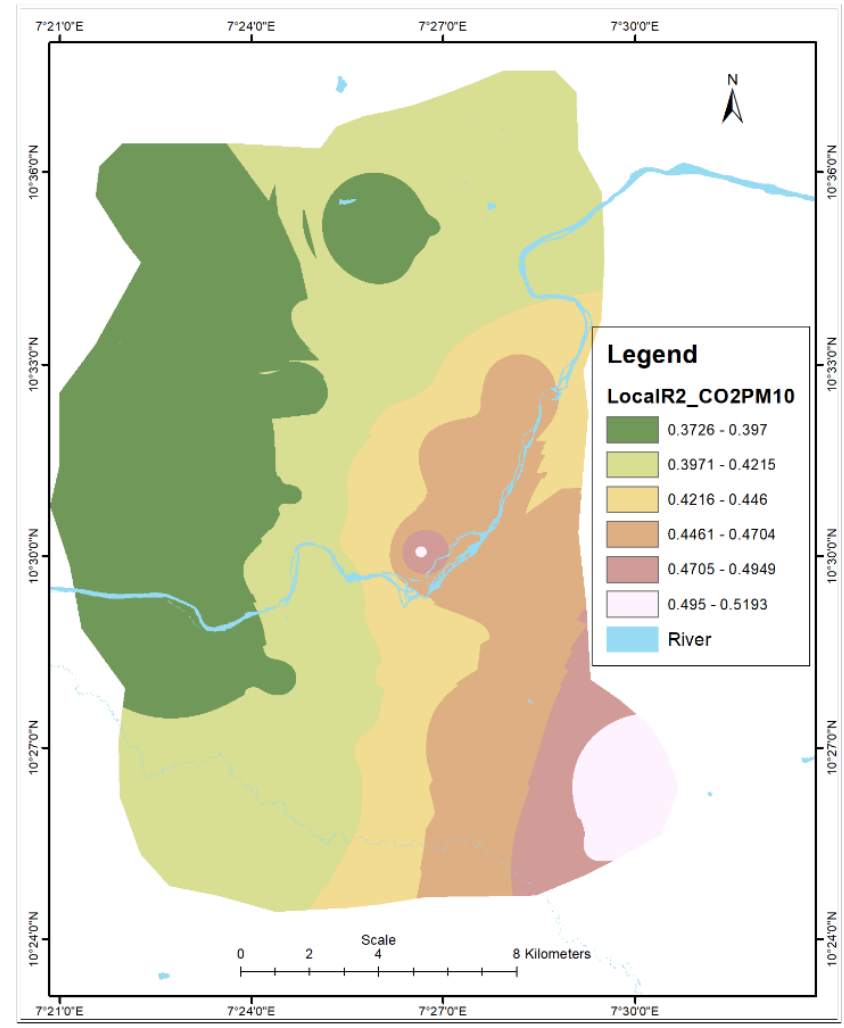

(d): $\mathrm{PM}_{10}$

Figure 5. Spatial variation in local $\mathrm{R}^{2}$ values for carbon dioxide prediction 
The analysis reveals a week relationship with $\mathrm{CO}, \mathrm{PM}_{2.5}$ and $\mathrm{PM}_{10}$. The Local $\mathrm{R}^{2}$ varies spatio-temporally across the metropolis ranging from 0.3659 to 0.5577 and 0.4188 to 0.5649 and 0.3726 to 0.5193 for $\mathrm{CO}, \mathrm{PM}_{2.5}$ and $\mathrm{PM}_{10}$ respectively as shown in Figure $5 \mathrm{~b}, \mathrm{c}$ and $\mathrm{d}$. The local $\mathrm{R}^{2}$ for $\mathrm{CO}$ also varies spatially across the metropolis. Higher values ranging between 0.4756 to 0.5577 were observed in the eastern part of the metropolis, while lower values ranging from 0.3659 to 0.4207 were observed in the western part of the metropolis. The local $\mathrm{R}^{2}$ value of $\mathrm{PM}_{2.5}$ and $\mathrm{PM}_{10}$ also varies spatially across the metropolis, with lower values ranging from 0.3726 to 0.4675 were observed in the south western and northern part of the metropolis, while higher values ranging from 0.4705 to 0.5849 were observed in the south eastern part of the metropolis. Thus, week association exist between $\mathrm{PM}_{2.5}$, $\mathrm{PM}_{10}$ emission and $\mathrm{CO}_{2}$ emission in Kaduna metropolis, which varies spatio-temporally.

Spatial Variation in Relationship between Particulate Matter $\mathbf{P M}_{2.5}$ and the other Air Pollutants $\left(\mathrm{CO}, \mathrm{SO}_{2}\right.$, $\mathrm{CO}_{2}$ and $\left.\mathrm{PM}_{10}\right)$

The GWR model for $\mathrm{PM}_{2.5}$ shows an AICc value of 363.59, 355.97, 369.90, 257.11 for $\mathrm{CO}, \mathrm{SO}_{2}, \mathrm{CO}_{2}$ and $\mathrm{PM}_{10}$ respectively and $\mathrm{R}^{2}$ value of $0.6206,0.7082,0.5810,0.9864$ equally for $\mathrm{CO}, \mathrm{SO}_{2}, \mathrm{CO}_{2}$ and $\mathrm{PM}_{10}$. This also implies that $\mathrm{PM}_{2.5}$ can best be used to model the concentration of $\mathrm{PM}_{10}$ than the other air pollutants as about $98.64 \%$ of the model can be accurately accounted for. While $\mathrm{CO}_{2}$ is also the weakest predictor among the pollutants, though its performance is also strong with an accuracy of about $58 \%$, as the variance accounted for by the regression model for the prediction of $\mathrm{PM}_{2.5}$ air pollutant.

The map of the local $\mathrm{R}^{2}$ values allow the visualization of the spatial varying relationships between particulate matters $\mathrm{PM}_{2.5}$ and gaseous air pollutants $\left(\mathrm{CO}, \mathrm{SO}_{2}, \mathrm{CO}_{2}\right)$ and $\mathrm{PM}_{10}$. The finding of the study for the local $\mathrm{R}^{2}$ as shown in Figure 6 reveals that the local $\mathrm{R}^{2}$ values with respect to $\mathrm{PM}_{10}$ exhibits slight spatial variability ranging from 0.9748 to 0.9893 . Higher $\mathrm{R}^{2}$ values of 0.985 to 0.9899 with respect to $\mathrm{PM}_{10}$, were observed in the northern and central part of the metropolis, while lower values ranging from 0.9749 to 0.9799 were observed in the southern part of the metropolis. This implies that $\mathrm{PM}_{2.5}$ emission have a very strong association with $\mathrm{PM}_{10}$ emission in Kaduna metropolis, and exhibits a near perfect association, most especially in the central and northern part of the metropolis as shown in Figure 6 a. 


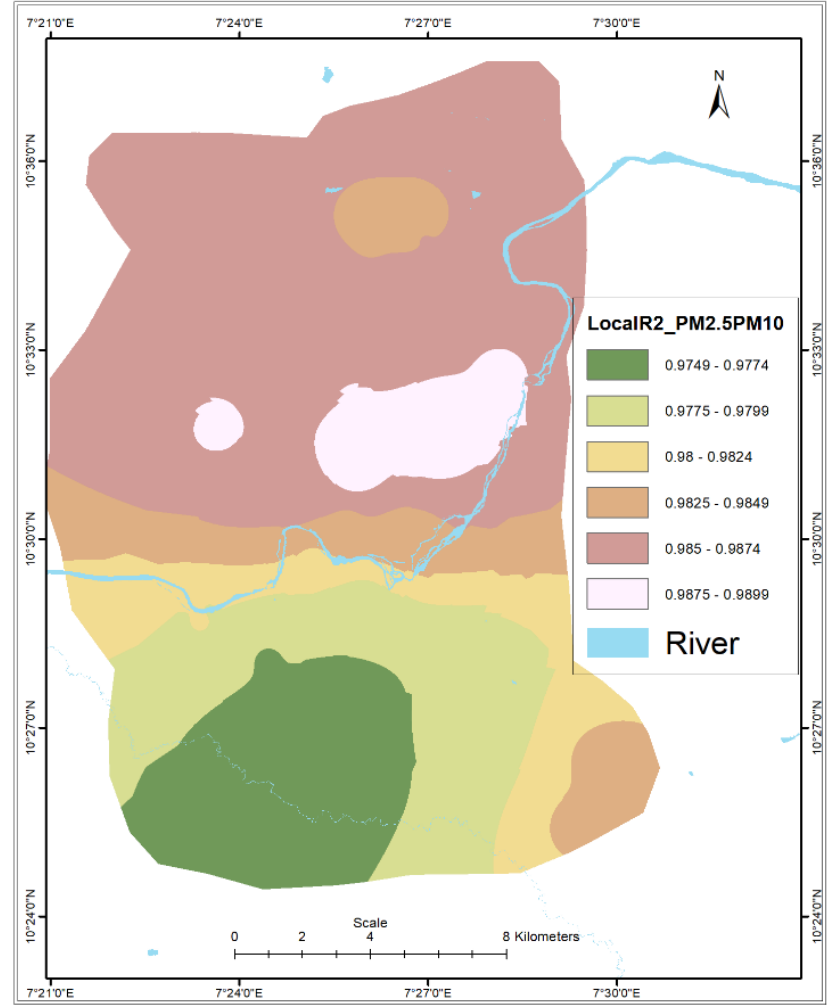

(a): $\mathrm{PM}_{10}$

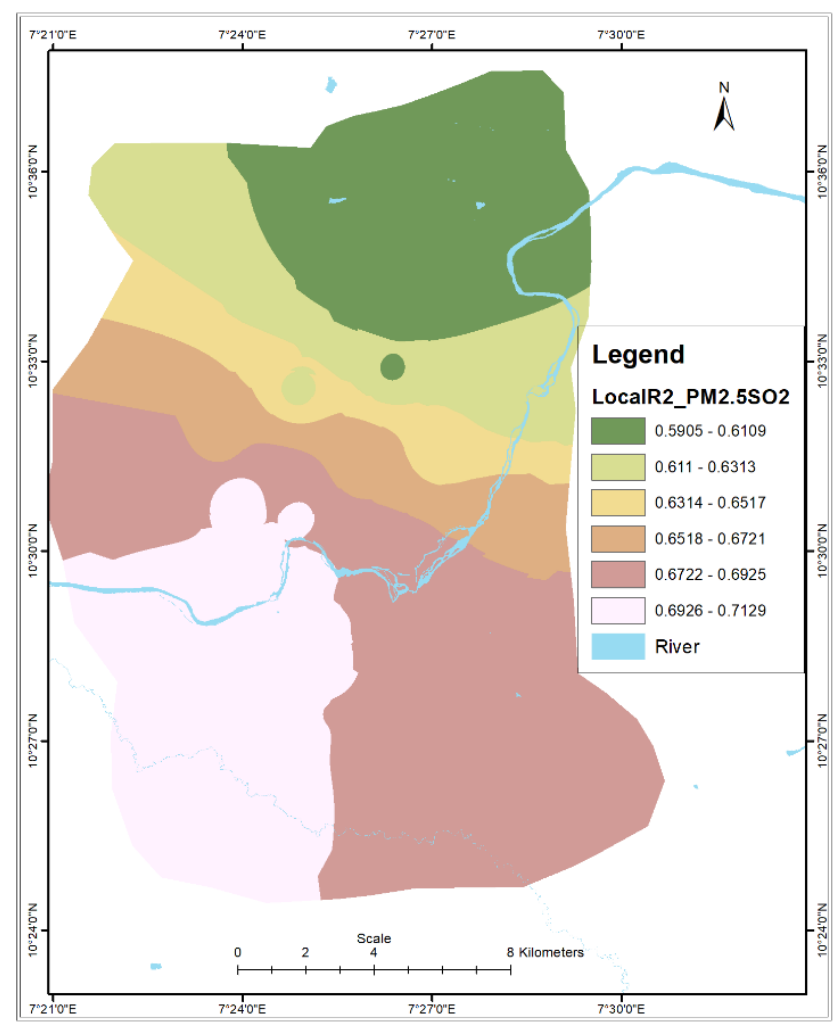

(c): $\mathrm{SO}_{2}$

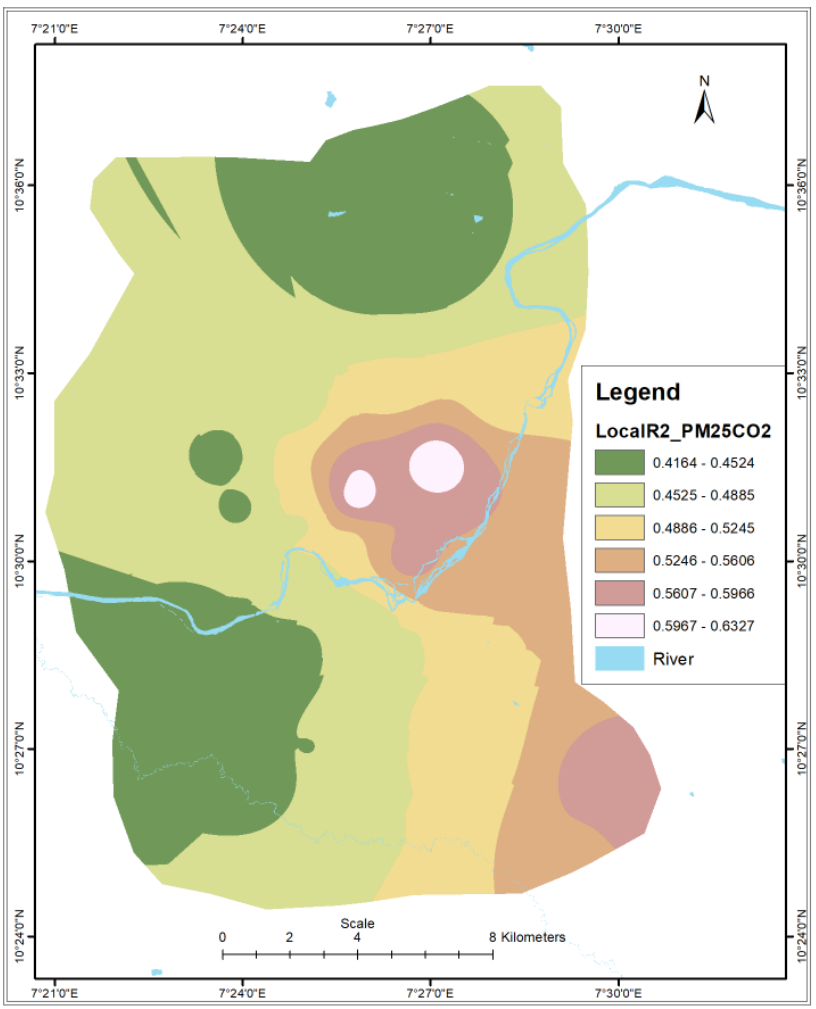

(b): $\mathrm{CO}_{2}$

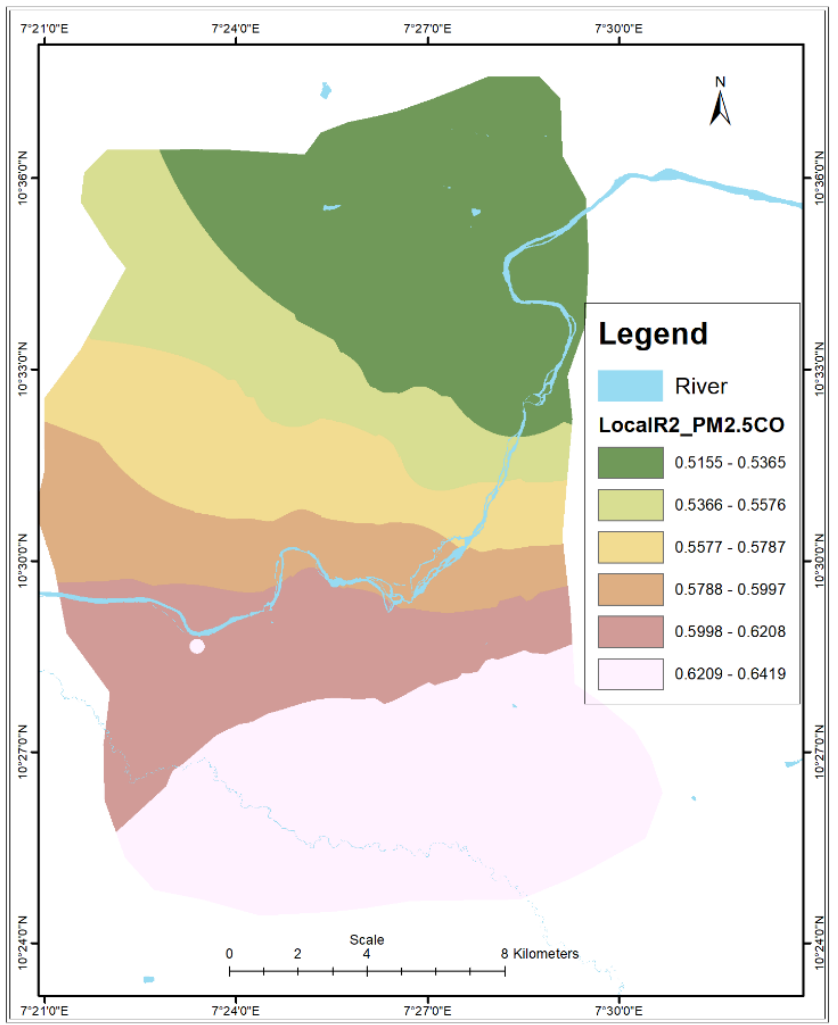

(d): $\mathrm{CO}$

Figure 6. Spatial variation in local $\mathrm{R}^{2}$ values for particulate matter $\left(\mathrm{PM}_{2.5}\right)$ prediction 
The analysis also shows a strong relationship with $\mathrm{CO}, \mathrm{SO}_{2}$ and $\mathrm{CO}_{2}$, and their Local $\mathrm{R}^{2}$ also varies spatiotemporally across the metropolis ranging from 0.5155 to $0.6419,0.5905$ to 0.7129 and 0.4164 to 0.6327 for $\mathrm{CO} \mathrm{SO}_{2}$ and $\mathrm{CO}_{2}$ respectively as shown in Figure $6 \mathrm{~b}$, c and d. the finding equally shows that the local $\mathrm{R}^{2}$ value for $\mathrm{CO}$ is relatively uniform across the metropolis, higher values ranging between 0.5998 to 0.6419 were observed in the southern part of the metropolis, while lower values ranging from 0.5155 to 0.5576 were observed in the northern part of the metropolis. The local $\mathrm{R}^{2}$ value of $\mathrm{SO}_{2}$ varies spatial across the metropolis, lower values ranging from 0.5905 to 0.6313 were observed in the Northern part of the metropolis, while higher values ranging from 0.6722 to 0.7129 were observed in the southern part, the highest values are in the south western part of the metropolis.

The local $\mathrm{R}^{2}$ value of $\mathrm{CO}_{2}$ also varies spatial across the metropolis, higher values from 0.5246 to 0.6327 were observed in the Eastern part of the metropolis, while lower values from 0.4164 to 0.4885 were observed in the south western and northern part of the metropolis. Thus, a stronger association exist between $\mathrm{SO}_{2}$ emission and $\mathrm{PM}_{2.5}$ than both $\mathrm{CO}$ and $\mathrm{CO}_{2}$ emission in Kaduna metropolis, which varies spatiotemporally.

Spatial Variation of Relationships between Particulate Matter $\mathrm{PM}_{10}$ and the other Air Pollutants $\left(\mathrm{CO}, \mathrm{SO}_{2}\right.$, $\mathrm{CO}_{2}$ and $\mathrm{PM}_{2.5}$ )

The GWR model for $\mathrm{PM}_{10}$ shows an AICc value of 412.013, 401.705, 418.62, 303.80 for $\mathrm{CO}, \mathrm{SO}_{2}, \mathrm{CO}_{2}$ and $\mathrm{PM}_{2.5}$ respectively and $\mathrm{R}^{2}$ value of $0.6200,0.7275,0.5717,0.987$ equally for $\mathrm{CO}, \mathrm{SO}_{2}, \mathrm{CO}_{2}$ and $\mathrm{PM}_{2.5}$. This implies that $\mathrm{PM}_{10}$ can best be used to model the concentration of $\mathrm{PM}_{2.5}$ than the other air pollutants as about $98.64 \%$ of the model can be accurately accounted. While $\mathrm{CO}_{2}$ is the weakest predictor among the pollutants, though its performance is also strong with an accuracy of about $57 \%$, as the variance accounted for by the regression model for the prediction of $\mathrm{PM}_{10}$ air pollutant.

The result of the local $\mathrm{R}^{2}$ values for $\mathrm{PM}_{10}$ is shown in Figure 7. The result further reveals that the model using $\mathrm{PM}_{2.5}$ to predict $\mathrm{PM}_{10}$ has a Local $\mathrm{R}^{2}$ value range of 0.9749 to 0.9899 , and the spatial analysis of its performance shows that the model performs better in the northern part of the metropolis than the southern part of the metropolis. Higher $\mathrm{R}^{2}$ values of 0.9836 to 0.9899 with respect to $\mathrm{PM}_{2.5}$, were observed in the northern and central part of the metropolis, while lower values ranging from 0.9749 to 0.9792 were observed in the southern part of the metropolis. These Local $\mathrm{R}^{2}$ values implies that $\mathrm{PM}_{10}$ emission have a very strong association with $\mathrm{PM}_{2.5}$ emission in Kaduna metropolis, exhibiting a near perfect association, most especially in the central and northern part of the metropolis as shown in Figure 7 a. 


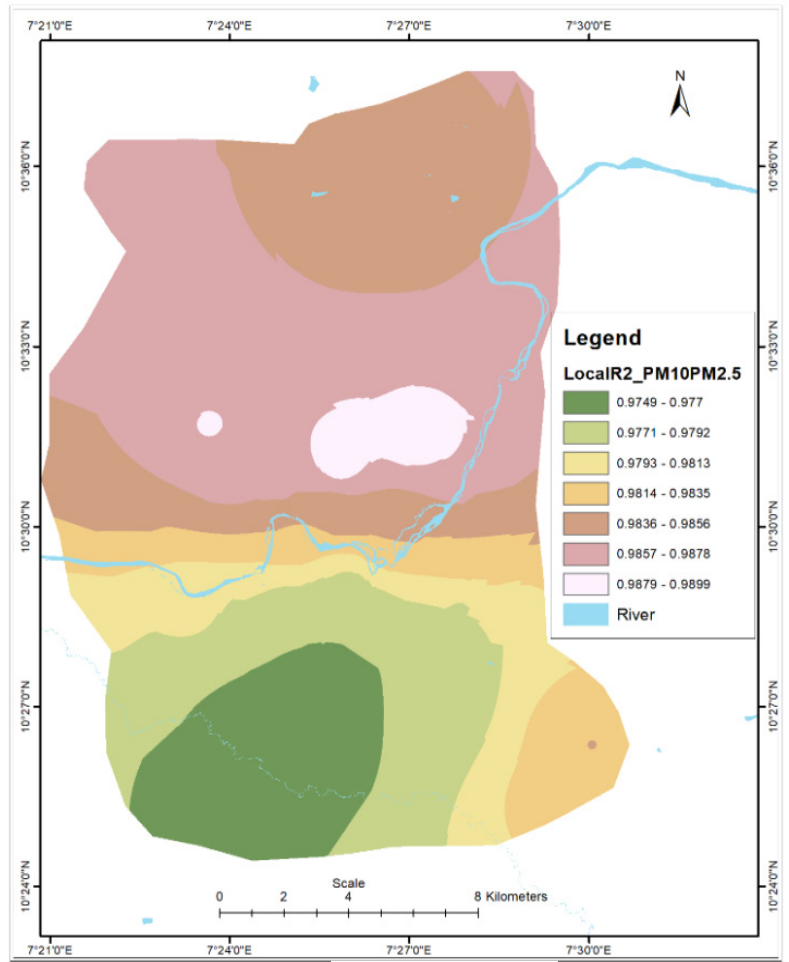

(a): $\mathrm{PM}_{2.5}$

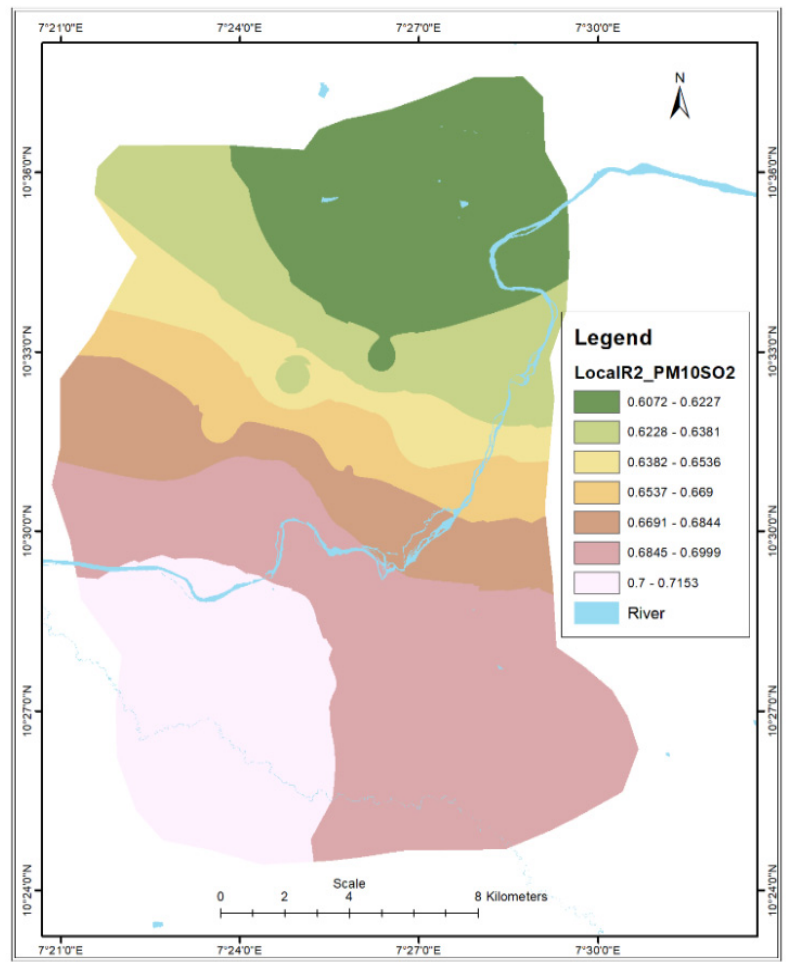

(c): $\mathrm{SO}_{2}$

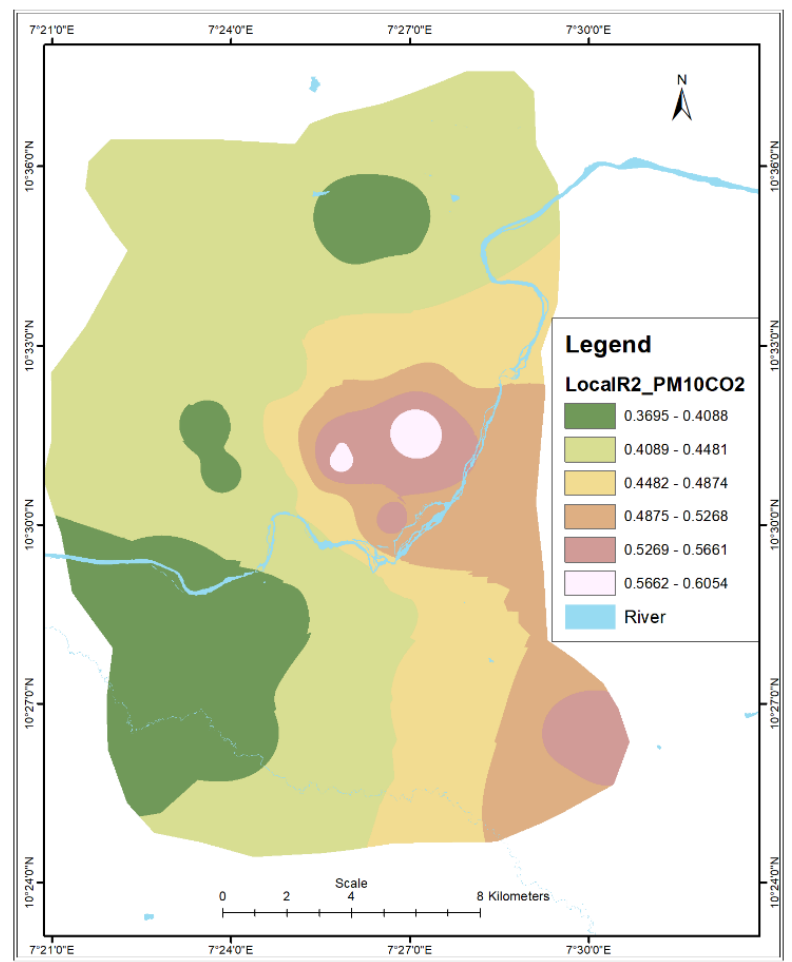

(b): $\mathrm{CO}_{2}$

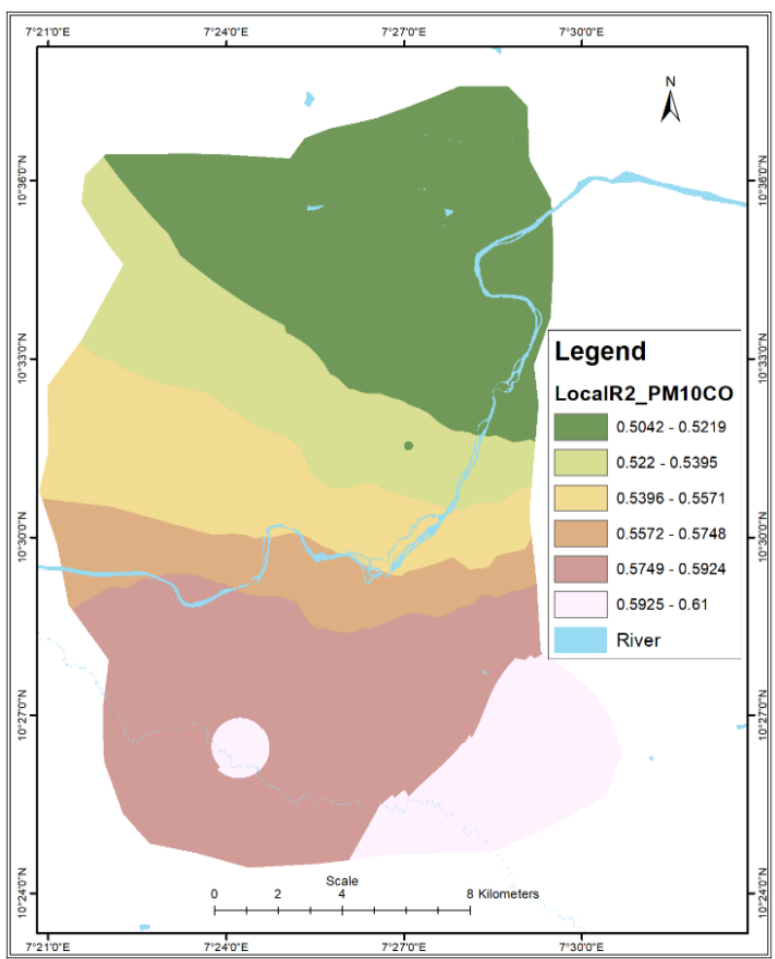

(d): $\mathrm{CO}$

Figure 7. Spatial variation in local $\mathrm{R}^{2}$ values for particulate matter $\left(\mathrm{PM}_{10}\right)$ prediction

The analysis of the local $\mathrm{R}^{2}$ for $\mathrm{PM}_{10}$ also shows a strong relationship with $\mathrm{CO}, \mathrm{SO}_{2}$ and $\mathrm{CO}_{2}$, whose Local $\mathrm{R}^{2}$ also varies spatiotemporally across the metropolis ranging from 0.5042 to $0.6100,0.6072$ to 0.6999 and 0.3695 to 0.6054 for $\mathrm{CO} \mathrm{SO}_{2}$ and $\mathrm{CO}_{2}$ respectively as shown in Figure $5.10 \mathrm{~b}$, c and d. the finding equally show local $\mathrm{R}^{2}$ 
value for $\mathrm{CO}$ is relatively uniform across the metropolis, higher values ranging between 0.5749 to 0.61 were observed in the southern part of the metropolis, while lower values ranging from 0.5042 to 0.5395 were observed in the northern part of the metropolis. The local $\mathrm{R}^{2}$ value with respect to $\mathrm{SO}_{2}$ also varies spatial across the metropolis, lower values ranging from 0.6072 to 0.6381 were observed in the Northern part of the metropolis, while higher values ranging from 0.6845 to 0.6999 were observed in the southern part, the highest values are in the south western part of the metropolis. The local $\mathrm{R}^{2}$ value of $\mathrm{CO}_{2}$ also varies spatial across the metropolis, higher values from 0.5269 to 0.6054 were observed in the Eastern part of the metropolis, while lower values from 0.3695 to 0.4481 were observed in the south western and northern part of the metropolis. Thus, implying that stronger association exist between $\mathrm{SO}_{2}$ emission and $\mathrm{PM}_{10}$ than $\mathrm{CO}$ and $\mathrm{CO}_{2}$ emission in Kaduna metropolis, which varies spatiotemporally.

\section{Conclusion}

Findings from this research show that air quality in Kaduna Metropolis varies from one location to the other. Knowledge of the spatial relations among these gases is crucial to understanding their atmospheric concentrations and lifetimes and the environmental impacts that can be expected with modifications to their sources and sinks.

The study concludes that there is a non - perfect linear relationship existing between the air pollutants $\mathrm{CO}, \mathrm{SO}_{2}$, $\mathrm{CO}_{2}, \mathrm{PM}_{2.5}$ and $\mathrm{PM}_{10}$ in Kaduna Metropolis. Further, the use of GWR to establish the existence of locally varying relationship between the variables was also successful. The study concludes that the relationship between the air pollutants varies spatially across Kaduna Metropolis. However, highest $\mathrm{R}^{2}$ were mostly in the central and southern part of the metropolis except for $\mathrm{PM}_{2.5}$ and $\mathrm{PM}_{10}$ whose $\mathrm{R}^{2}$ values was higher in the Northern part of the metropolis. Equally, $\mathrm{CO}$ has the strongest association with $\mathrm{SO}_{2}, \mathrm{SO}_{2}$ has the strongest association with $\mathrm{PM}_{2.5}$ and $\mathrm{PM}_{10}, \mathrm{CO}_{2}$ with $\mathrm{SO}_{2}, \mathrm{PM}_{10}$ has the highest association with $\mathrm{PM}_{2.5}$, likewise $\mathrm{PM}_{2.5}$ with $\mathrm{PM}_{10}$.

Thus, the GWR analysis of the air pollutants data of Kaduna Metropolis have proven to be of significance in the study of air pollutants not only of sample points, but have provides an insight into the mechanism involves in the study of air pollutants $\left(\mathrm{CO}, \mathrm{SO}_{2}, \mathrm{CO}_{2}, \mathrm{PM}_{2.5}\right.$ and $\left.\mathrm{PM}_{10}\right)$. Hence, this study recommends the use of GWR to model air pollutants in cities with limited monitoring capability. It equally recommends that concerted efforts should be made towards improving power supply in the country and also, developing and promoting alternative energy with less emission for automobile and small generators use other than fossil fuel.

\section{References}

Abaje, I. B., Ati, O. F., \& Ishaya, S. (2009). Nature of Portable Water Supply and Demand $\quad$ in Jema'a Local Government Area of Kaduna State, Nigeria. Research Journal of Environmental and Earth Sciences, 1(1), $16-21$.

Adedeji, O. H., Olasumbo, O., \& Oluwaseun, T. O. (2016). Mapping of Traffic-Related Air Pollution Using GIS Techniques in Ijebu-Ode, Nigeria. Indonesian Journal of Geography, 48(1), 73-83. https://doi.org/10.22146/ijg.12488

Agan, P. N. (2019). Impacts of Anthropogenic Factors on Urban Air Quality in Lagos Metropolis. Journal of Geography and Geology, 11(2), 35-39. https://doi.org/10.5539/jgg.v11n2p35

Akpu, B. (2012). An Analysis of Spatio-Temporal Gowth of Kaduna Metropolis and its Enviromental Consequences in Kaduna, Nigeria, Unpublished PhD Dissertation submitted to the Department of Geography, Bayero University, Kano.

Aliyu, Y. A., \& Botai, J. O. (2018). Reviewing the local and global implications of air pollution trends in Zaria, Northern Nigeria. Urban Climate, 26, 51-59. https://doi.org/10.1016/j.uclim.2018.08.008

Allegrini, I., \& Costabile, F. (2002). A new approach for monitoring atmospheric pollution in urban environment. Global Conference Building a Sustainable World. San-Paolo.

Aremu, J. K. (2014). The Language of Metrology, Cee Kay Bee printers, VV4, Keffi Road, Kaduna, Nigeria.

Banja, M., Como, E., Murtaj, B., \& Zotaj, A. (2010). Mapping Air Pollution in Urban Tirana Area Using GIS, International Conference SDI 2010 - Skopje.

Begum, B. A., Kim, E., Biswas, S. K., \& Hoopke, P. K. (2004). Investigation of Sources of Atmospheric Aerosol at Urban and Semi Urban Areas in Bangladesh. Atmospheric Environment, 38(1), 3025-3038. https://doi.org/10.1016/j.atmosenv.2004.02.042

Bellander, T., Berglind, N., Gustavsson, P., Jonson, T., Nyberg, F., Pershagen, G., \& Järup, L. (2001). Using Geographic Information Systems to Assess Individual Historical Exposure to Air Pollution from Traffic and 
House Heating in Stockholm. Environ Health Perspect, 109(1), 633-639. https://doi.org/10.1289/ehp.01109633

Brezzi, M., \& Sanchez-Serra, D. (2014). Breathing the Same Air? Measuring Air Pollution in Cities and Regions, OECD Regional Development Working Papers, 2014/11, OECD Publishing.

Briggs, D. (2007). The Role of GIS: Coping with Space (And Time) in Air Pollution Exposure Assessment. Journal of Toxicology and Environmental Health, 68(13-14), 1243-61. https://doi.org/10.1080/15287390590936094

Das, R. C., \& Behera, D. K. (2008). Environmental Science Principles and Practice. Prentice, Hall of India New Delhi India.

Dons, E., Van Poppel, M., Kochan, B., \& Wets, G. (2013). Modeling temporal and spatial variability of trafficrelated air pollution: hourly land use regression models for black carbon. Atmos. Environ., 74(8), $237-246$. https://doi.org/10.1016/j.atmosenv.2013.03.050

Dubey, B. (2014). Application of air pollution models and remote sensing in Air Quality Management. Indian Journal of Applied Research, 4(5), 266-268. https://doi.org/10.15373/2249555X/MAY2014/78

EEA-WHO. (2002). Children's health and environment: a review of evidence. In Tamburlini, G., von Ehrenstein, O. S., \& Bertolini, R. (Eds.), A joint report from the European Environment Agency and the World Health Organization Regional Office for Europe. WHO Regional Office for Europe.

Enkhtur, B. (2013). Geostatistical Modelling and Mapping of Air Pollution. MSc. Thesis. Faculty of GeoInformation Science and Earth Observation, University of Twente, Enschede. the Netherlands.

ESRI. (2007). GIS for Air Quality. Retrieved April 7, 2017, from http:// www.esri.com/library/bestpractices/airquality.pdf

Garg, S. K., Garg, R., \& Garg, R. (2006). Environmental Science and Ecological Studies. Delhi, Khanna Publishers, Hyderabad, India.

Gupta, P., \& Follette-Cook, M. (2017). Satellite Derived Annual PM 2.5 Data Sets in Support of United Nations Sustainable Development Goals, Applied Remote Sensing Training, March 15-29, 2017, National Aeronautics and Space Administration.

Habitat, II. (1996). Report of the United Nations Conference on Human Settlements (Habitat II), Istanbul.

Hadjimitsis, D. G., Nisantzi, A., Themistocleous, K., Matsas, A., \& Trigkas, V. P. (2010). Satellite remote sensing, GIS and sun-photometers for monitoring $\mathrm{PM}_{10}$ in Cyprus: issues on public health. Proc. SPIE., 78(6). https://doi.org/10.1117/12.865120

IPCC. (2014). Climate Change 2014: Synthesis Report. Contribution of Working Groups I, II and III to the Fifth Assessment Report of the Intergovernmental Panel on Climate Change [Core Writing Team, R.K. Pachauri and L.A. Meyer (eds.)], IPCC, Geneva, Switzerland.

Ladan, S. L. (2013). Examining Air Pollution and Control Measures in Urban Centers of Nigeria. International Journal of Environmental Engineering and Management, 4(6), 621-628.

Matejicek, L. (2005). Spatial Modelling of Air Pollution in Urban Areas with GIS: A Case Study on Integrated Database Development. Advances in Geosciences, 4, 63-68. https://doi.org/10.5194/adgeo-4-63-2005

Mishra, P. C. (2008). Fundamentals or Air and Water Pollution. New Delhi: APH publishers limited.

Mwenda, L. P. (2011). Geostatistical analysis of air pollution using models, in situ and remote sensed data. MSc Thesis, University of Twente, Faculty of Geo-Information and earth Observation, ITC, Enschede.

N'uñez-Alonso, D., P'erez-Arribas, L.V., Manzoor, S., \& C'aceres, J. O. (2019). Statistical Tools for Air Pollution Assessment: Multivariate and Spatial Analysis Studies in the Madrid Region. Journal of Analytical Methods in Chemistry. https://doi.org/10.1155/2019/9753927

Nation Population Commission (NPC). (1991). Census figures for 1991.

Nation Population Commission (NPC). (2009). Census figures for 2006.

Nwude, M. O. (2006). A sustainable option for solid waste management in kaduna metropolis Unpublished M.Sc thesis Ahmadu Bello University, Zaria, Kaduna.

Odindi, J., Mhangara, P., \& Kakembo, V. (2012). Remote sensing land-cover change in Port Elizabeth during South Africa's democratic transition. South African Journal of Science, 108(5/6), 1-7. https://doi.org/10.4102/sajs.v108i5/6.886 
Olajire, A. A., Azeez, L., \& Oluyemi, E. A. (2011). Exposure to hazardous air pollutants along Oba Akran road, Lagos - Nigeria. Chemosphere, 84(8), 1044-1051. https://doi.org/10.1016/j.chemosphere.2011.04.074

Paton-Walsh, C., Guérette, E., Emmerson, K., Cope, M., Kubistin, D., Humphries, R., ... Chambers, S. (2018). Urban Air Quality in a Coastal City: Wollongong during the MUMBA Campaign. Atmosphere, (9), 500. https://doi.org/10.3390/atmos9120500

Rahman, S. R. A., Ismail, S. N. S., Raml, M. F., Latif, M. T., Abidin, E. Z., \& Praveena, S. M. (2015). The Assessment of Ambient Air Pollution Trend in Klang Valley, Malaysia, World Environment, 5(1), 1-11.

Rahmatizadeh, S. H., Delavar, M. R., \& Motessadi, S. (2003). Application of GIS in Air Quality Management, Proc. First national Air Pollution congress, Tehran, Iran.

Raju, H. P., Partheeban, P., \& Hemamalini, R. R. (2012). Urban Mobile Air Quality Monitoring Using GIS, GPS, Sensors and Internet. International Journal of Environmental Science and Development, 3(4), 323-327. https://doi.org/10.7763/IJESD.2012.V3.240

Revi, A., Satterthwaite, D. E., Aragón-Durand, F., Corfee-Morlot, J., Kiunsi, R. B. R., Pelling, R., ... Solecki, W. (2014). Urban areas. In C. B. Field, V. R. Barros, D. J. Dokken, K. J. Mach, M. D. Mastrandrea, T. E. Bilir, ... L. L. White (Eds.), Climate Change 2014: Impacts, Adaptation, and Vulnerability, Part A: Global and Sectoral Aspects (pp. 535-612). Contribution of Working Group II to the Fifth Assessment Report of the Intergovernmental Panel on Climate Change Cambridge University Press, Cambridge, United Kingdom and New York, NY, USA.

Rio. (1992). The Rio Declaration on Environment and Development, The United Nations Conference on Environment and Development.

Robichaud, A., Menard, R., Zaïtseva, Y., \& Anselmo, D. (2016). Multi-pollutant surface objective analyses and mapping of air quality health index over North America. Air Qual Atmos Health, 9, 743-759. https://doi.org/10.1007/s11869-015-0385-9

Sameen, M. I., Al Kubaisy, M. A., Nahhas, F. H., Ali, A. A., Othman, N., \& Hason, M. (2014). Sulfur Dioxide $\left(\mathrm{SO}_{2}\right)$ Monitoring Over Kirkuk City Using Remote Sensing Data. J Civil Environ Eng, 4(155), 1-6.

Satterthwaite, D. (2007). The Transition to a Predominantly Urban World and its Underpinnings, Human Settlements Discussion Paper, IIED, London.

Smallbone, K. (1998). Mapping ambient urban air pollution at the small area scale: a GIS approach. Unpublished $\mathrm{PhD}$ thesis, Department of Geography, University of Huddersfield. UK.

Tiwari, K., \& Singh, A. K. (2014). Hydrogeochemical investigation and groundwater quality assessment of pratapgarh district, Uttar Pradesh. Journal of the Geological Society of India, 83(3). https://doi.org/10.1007/s12594-014-0045-y

UN. (2019). World Urbanization Prospects, 2018 Revision, Department of Economic and Social Affairs, United Nation.

Van der Kassteele, J., Stein, A., \& Dekkers, A. L. M. (2006). Statistical air quality mapping, PhD Thesis, Wagenigen Universiret. Wagennigen.

Wu, P. (2006). Modeling Transportation Related Emissions Using GIS. Transportation Technology and Policy Graduate Group, Institute of Transportation Studies, the University of California, Davis, November 2006.

Yao, Y., He, C., Li, S., Ma, W., Li, S., Yu, Q., ... Zhang, Y. (2019) Properties of particulate matter and gaseous pollutants in Shandong, China: Daily fluctuation, influencing factors, and spatiotemporal distribution. Science of The Total Environment, 660, 384-394. https://doi.org/10.1016/j.scitotenv.2019.01.026

Zhu, G., Guo, Q., Xiao, H., Chen, T., \& Yang, J. (2017). Multivariate statistical and lead isotopic analyses approach to identify heavy metal sources in topsoil from the industrial zone of Beijing Capital Iron and Steel Factory. Environmental Science and Pollution Research, 24(17), 14877-14888. https://doi.org/10.1007/s11356-0179055-9

Zhu, Y., Hinds, W. C., Kim, S., \& Sioutas. C. (2002). Concentration and size distribution of ultrafine particles near a major highway. J Air Waste Manag Assoc., 52(9), 1032-1042. https://doi.org/10.1080/10473289.2002.10470842 


\section{Copyrights}

Copyright for this article is retained by the author(s), with first publication rights granted to the journal.

This is an open-access article distributed under the terms and conditions of the Creative Commons Attribution license (http://creativecommons.org/licenses/by/4.0/). 